\title{
IRRIGATION AND THE ORIGINS OF THE SOUTHERN MOCHE STATE ON THE NORTH COAST OF PERU
}

\author{
Brian R. Billman
}

\begin{abstract}
In this paper, I examine the role that irrigation played in the formation of the Southern Moche state in the Moche Valley, Peru. Specifically, I attempt to test Wittfogel and Steward's hydraulic model, which postulates that in certain arid environments, the managerial requirements of construction and maintenance of irrigation systems played a crucial role in the formation of centralized polities. I formulate and evaluate four hypotheses concerning the role of irrigation systems in the Moche Valley. Those hypotheses are then evaluated using settlement pattern data drawn from two surveys that cover the entire coastal section of the valley and provide information on 910 archaeological sites. Based on those data, I present a sequence of political development for the valley from the formation of the first autonomous village in the Late Preceramic period (2500-1800 B.C.) to the zenith of the Southern Moche state. Evaluation of the four hypotheses indicates that the managerial requirements of irrigation were relatively unimportant; rather, warfare, highland-coastal interaction, and political control of irrigation systems created opportunities for leaders to form a highly centralized, territorially expansive state sometime between A.D. 200 and 700.
\end{abstract}

En el presente artículo, examino el rol que jugó la irrigación en la formación del estado Moche Sureño en el valle de Moche, Perú. Específicamente, busco probar las hipótesis hidráulicas de Wittfogel y Steward, las cuales postulan que en ciertos medio ambientes áridos, la necesidad. de una administración de la construcción y el mantenimiento de los sistemas de irrigación jugaron un rol crucial en la formación de organizaciones centralizadas. Formulo y evalúo cuatro hipótesis tomando en consideración el rol de que de los sistemas de irrigación jugaron en la formación del estado Moche Sureño. Los datos del patrón de asentamiento son usados para evaluar las hipótesis. Los datos han sido recopilados a través de dos prospecciones, las cuales cubren toda la sección costeña del valle y brindan información de más de 910 sitios. Basado en dichos datos, presento una secuencia de desarrollo político para el valle desde la formación de la primera villa autónoma en el periodo Precerámico Tardío (2500-1800 a.C.) hasta el apogeo del estado Moche Sureño. Los análisis indican que los requisitos de una administración de la irrigación no tuvieron una importancia relativa en la formación del estado Moche Sureño; por el contrario los conflictos, la interacción costa-sierra, y el control político de los sistemas de irrigación crearon oportunidades para que los líderes formaran un estado altamente centralizado y territorialmente expansivo en algún momento entre los 200 y 700 d.C.

How does leadership change from its charismatic, sporadic, and personal form to become centralized, institutionalized, and permanent? [Service 1985:176].

I $\mathrm{n}$ the middle part of the Early Intermediate period (EIP) (400 B.C-A.D. 800), a large, regional state formed in the Moche Valley on the north coast of Peru. Centered at the site of Moche, this polity is arguably one of the earliest regional states to emerge in the Andean region. Referred to here as the Southern Moche state, it was a highly centralized, hierarchically organized political system in which leaders exercised considerable economic, military, and ideological power (Bawden 1996:108-168; Billman 1996:311-335; Moseley 1992:162-184; Shimada 1994; Topic 1982; Uceda 1997). Leaders of this state directed the construction of massive pyramids, led the conquest of a large section of the north coast of Peru, and organized the production of unprecedented amounts of finely crafted gold objects, pottery, and textiles.

Irrigation has often been cited as an important factor in the development of state-level societies on the central Andean coast (Haas 1987; Moseley 1974;

Brian R. Billman = Department of Anthropology, 301 Alumni Bldg, CB 3115, University of North Carolina at Chapel Hill, Chapel Hill, NC 27599-31151. Email: bbillman@email.unc.edu

Latin American Antiquity, 13(4), 2002, pp. 371-400

Copyright $\odot 2002$ by the Society for American Archaeology 


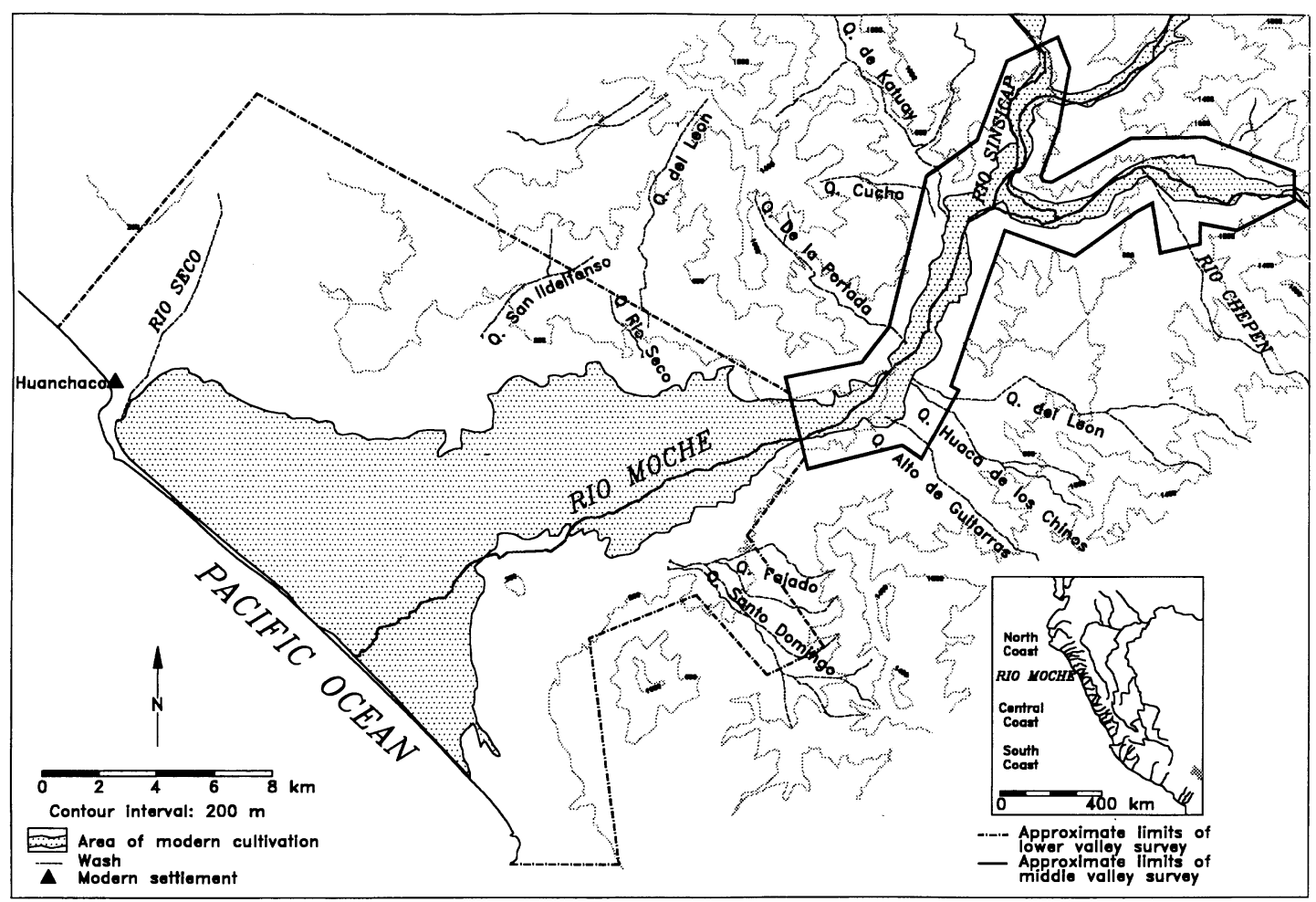

Figure 1. Location of lower- and middle-valley surveys, Moche Valley, Peru. The lower-valley survey was conducted by Michael Moseley during the Chan Chan-Moche Valley Project; the middle-valley survey was conducted by the author in 1990 and 1991.

Sanders and Marino 1970; Steward 1949, 1971; cf. Lanning 1967; Rowe 1963). Because the coast lacks any significant annual rainfall, agriculture is dependent upon irrigation. Consequently, since its introduction around 1800 B.C., irrigation has been essential to the survival of sedentary populations and centralized polities. Few attempts, however, have been made to systematically evaluate the role that irrigation played in political evolution on the central Andean coastline.

I use Wittfogel and Steward's hydraulic model as a heuristic device for examining the origins of the Southern Moche state. The hydraulic hypothesis postulates that the managerial requirements of construction and maintenance of irrigation systems played a crucial role in the formation of state-level polities in certain arid environments. I formulate a series of four testable hypotheses concerning the role of irrigation systems that are then evaluated using settlement pattern data from my survey of the middle Moche Valley and Michael Moseley's survey of the lower valley (Figure 1) (Billman 1996). I present a sequence of political development from the for- mation of the first autonomous village in the Late Preceramic period to the zenith of the Southern Moche state. Analysis of the development of irrigation and political centralization indicates that the managerial requirements of irrigation were probably relatively unimportant; rather, I propose that warfare, highland-coastal interaction, and political control of irrigation systems created opportunities for leaders to form a highly centralized state.

\section{A Single Moche State, Two Moche States, or Many Moche Chiefdoms?}

Definitions of a state are almost as varied as definitions of culture. Researchers studying different aspects of the state stress different characteristics. Although definitions vary, they are in agreement that the state is a general form of social organization that is distinct from other forms in that states (1) have relatively permanent institutionalized forms of leadership (not ephemeral rule by charismatic leaders); (2) have specialized, hierarchical administrative structures (states are bureaucratic); (3) encompass fixed territories (they are organized on the basis of 
land, not just kinship); (4) use some form of tribute collection to finance political activities; and (5) exercise political control through the use of positive and negative sanctions.

Studies conducted over the last three decades demonstrate that Moche political organizations probably had all five of these key attributes of the state (Bawden 1996; Billman 1996; Mosley 1992; cf. Schaedel 1985). The Southern Moche state appears to have existed for 400 to 600 years. Archaeological evidence shows considerable continuity in iconography, ceremonial architecture, and administrative structure throughout its existence (Topic 1977, 1982; Uceda 1997). The hierarchical administrative structure of the polity and its territorial limits are indicated by the distribution of administrative centers that have at least four tiers of hierarchy (Billman 1996:312-316; Conrad 1978; Donnan 1973; Topic 1977, 1982; Willey 1953: 178-233; Wilson 1988:222-224, 1995:200-202). Studies of monumental construction show that tribute was collected in the form of labor for massive construction projects (Hastings and Moseley 1975; Moseley 1975b; Topic 1977, 1982). The scope of tribute collection is indicated by Huaca del Sol, which contained over 140,000,000 adobe bricks (Hastings and Moseley 1975; Moseley 1975b). Iconographic representations of elite members of society conducting human sacrifice (Alva and Donnan 1993; Castillo and Donnan 1994; Donnan 1976) and the discovery of the physical remains of those sacrifices (Bourget 1997, 2001; Verano 2001) demonstrate that leaders exercised coercive sanctions.

Debate has recently shifted from whether or not there was a Moche state to the question of how many Moche states there were. The long-held view that the Mochica culture was incorporated into a single state centered in the Moche Valley (e.g., Shimada 1987) has been questioned as differences between the Lambayeque and Moche Valleys in ceramic style, monumental construction, and urban organization during the Moche phase have become apparent. Recently, Shimada (1994:1-6), Castillo and Donnan (1995), and Bawden (1996:227-262) have proposed the presence of a northern and a southern Moche polity in the Middle Moche phase (Moche III and IV), although Shimada still holds out the possibility of a brief period of southern hegemony over the northern polity in the latter part of the Middle Moche phase (Shimada 1994:2). Although resolution of the debate will require considerable additional research, current data from the Casma to the Chicama Valleys are sufficient to infer the development of at least one highly centralized, multivalley polity, the Southern Moche state, centered at the site of Moche, sometime between A.D. 200 and 800. Pampa Grande in the Lambayeque Valley probably was the center of a contemporary Northern Moche state (Shimada 1994).

\section{Theories of Irrigation and the Origins of the State}

The notion that early states were a solution (or adaptation) to social, economic, or environmental problems created by population pressure has influenced theories of state formation in anthropology since the 1940s (Binford 1983; Harris 1977; Johnson and Earle 1987; Sanders et al. 1979; Service 1962, 1975, 1985; Steward 1955; White 1949). In these formulationswhich are known as adaptationalist (Brumfiel and Earle 1987), integration (Haas 1982), or functional models-population growth resulted in resource shortages, thus creating the need for intensification of production. The increased need for centralized planning and management of capital investments in production in turn required the development of centralized political institutions.

Perhaps one of the most influential formulations of this functional view of state formation is Wittfogel and Steward's hydraulic hypothesis (Steward 1949, 1971; Wittfogel 1956, 1957, 1971). Wittfogel proposed that in certain, although not all instances, the managerial requirements of the construction of large irrigation systems led directly to the development of centralized, bureaucratic states:

A large quantity of water can be channeled and kept within bounds only by the use of mass labor; and this mass labor must be coordinated, disciplined, and led. Thus a number of farmers eager to conquer arid lowlands and plains are forced to invoke the organizational devices which-on the basis of premachine technology-offer the one chance of success: they must work in cooperation with their fellows and subordinate themselves to a directing authority [Wittfogel 1957:18].

Subsequently, numerous authors have suggested that the increased need for centralized planning and management of irrigation systems or other capital investments in production selected for centralized 
political systems (Cohen 1978, 1981; Johnson and Earle 1987; Sanders et al. 1979; Sanders and Price 1968; Wittfogel 1957). Irrigation is frequently cited as an important factor because of the perceived need for centralized planning and management to (1) construct and maintain canals, (2) integrate labor input from multiple households, (3) settle disputes and allocate water, and (4) direct the defense of the system (see Earle 1978:37-50; Sidky 1996:20-25).

Many researchers have examined the relationship between the construction and maintenance of irrigation systems and the growth of political authority in a wide range of contemporary and historic societies (Earle 1978; Gray 1963; Hunt and Hunt 1974; Leach 1959; Lees 1974; Mitchell 1973, 1976; Netting 1974; Sidky 1996, Spooner 1974). Others have attempted to test the hydraulic hypothesis by examining the temporal relationship between the occurrence of large-scale irrigation systems and the development of archaic states in Mesoamerica, the Andes, and the Near East (Adams 1966, 1968; Butzer 1976; Lanning 1967; Rowe 1963; Sanders and Marino 1970; Sanders and Price 1968). Results of these assessments have been decidedly mixed. While many investigators have found cases where the development of canal systems did not lead to highly centralized political organizations (Earle 1978; Gray 1963; Mitchell 1976), others have found cases where the managerial requirements of irrigation apparently did play an important role in political centralization (Emerson 1990; Hunt and Hunt 1974, Sidky 1996).

Functional theories of sociopolitical change have been justifiably criticized for (1) their focus on whole populations rather than individuals; (2) their limited consideration of the internal social dynamics of gender, class, and factions; and (3) their frequent use of population pressure as a prime mover (see Brumfiel 1992). However, the notion at the core of these theories-that chiefdom and state formation were the result of cooperative action for the benefit of the population-remains largely untested. Although functional models have fallen into disfavor, the possible cooperative aspects of political formation have resurfaced in the form of dual process theory, which proposes that leaders in early chiefdoms and states may have pursued either a cooperative corporate strategy or a more coercive network strategy (Blanton et al. 1996; Earle 2001; Trubitt 2000). In a similar vein, Renfrew (1974) has written about group-oriented vs. individualizing chiefdoms.
In contrast to this cooperative, functional view of irrigation and political formation, others have emphasized the political rather than the managerial aspects of irrigation (Earle 1978; Fried 1967:207-213; Haas 1981, 1982, 1987; Moseley 1974, 1975a; Stanish 1994). According to political models, differential access to basic resources resulted in social inequality and provided an emerging elite stratum with a source of economic power. By denying or rewarding individuals with access to basic goods or productive facilities, leaders achieved centralized political control of a social group. In addition, control of surplus production from irrigation systems provided a means for aspiring leaders to finance a wide range of political economic activities, such as feasting, monumental construction, public rituals, craft production, exchange, trade, or raiding. Carefully manipulated, the collection, redistribution, and investment of surplus agricultural production, which is known as staple finance (D'Altroy and Earle 1985; Earle 1987), allowed leaders to legitimize their elevated status, create networks of political allies, conquer adjacent areas, and make further capital investments in production (Billman 1999:132-135; Earle 1997:75-89; Sidky 1996: 49-75; Stanish 1994:314-315). Thus, irrigation systems created opportunities for leaders to expand their political power base and the political economy.

For the central Andean coast, political models have been proposed by Moseley $(1974,1975 a)$ and Haas $(1982,1987)$. In their formulations, the physical control of irrigation canals by an emerging elite social stratum - not population pressure or management-led to increased political centralization during the Initial period (1800-900 B.C.). In short, the degree of political centralization was not related to the scale and complexity of the productive system, but to the potential for individuals to manipulate the productive system to create social inequality and political control.

The formulation of these two contradictory perspectives - the hydraulic hypothesis and political models (Brumfiel and Earle 1987) — provides a useful contrastive tool for the empirical examination of the role irrigation played in the formation of centralized polities. Each of these perspectives emphasize different causal variables: cooperation and the managerial requirements of production vs. social stratification and political control. Arguably, these 
variables may have worked in tandem to create political centralization, one of them may have dominated the process, or some other set of factors may have played a crucial role.

\section{Defining the Managerial Requirements of Irrigation in the Moche Valley}

The hydraulic hypothesis proposes that political centralization is directly related to the size of irrigation systems. The primary problem in testing the model is establishing a priori the relationship between the size of an irrigation system and the scale of centralized polity required to construct and maintain it. Without question, small-scale irrigation systems can be constructed and maintained by local communities without formal centralized political organizations (Earle 1978; Gray 1963; Mitchell 1976; Netting 1974; Spooner 1974). At the other extreme, large regional irrigation systems clearly do require centralized management (Sidky 1996; Wittfogel 1957). Between these two extremes-small local systems and large regional systems - the hydraulic hypothesis should predict a threshold at which formal centralized political structures emerged.

Several functional-oriented theorists have proposed or implied threshold values for levels of political centralization based on group size (Johnson and Earle 1987; Service 1962). Statistical analysis has indicated that to some degree population size and the number of administrative levels in a polity are correlated (Feinman 1995:259-261; Feinman and Neitzel 1984). Although no theorist has proposed hard-and-fast expectations, functional-oriented theorists generally agree that communities with populations in the hundreds usually have only one level of political hierarchy, i.e., a village headman. Simple chiefdoms have populations in the thousands and two levels of hierarchy. Complex chiefdoms have three levels of administration and typically have populations in the tens of thousands. States encompass large regions, control even larger populations, and have more than three levels of administration. The premise of these threshold values is that a certain degree of central management and political control is required for each population level.

By examining three specific types of management activities required for the construction and use of irrigation systems, these population and spatial thresholds can be applied to the problem of irrigation and the development of political centralization.
Groups using irrigation systems face three types of management problems: (1) constructing and maintaining canals, (2) integrating households that use a particular canal, and (3) settling disputes and allocating water among canal systems (Earle 1978). Analysis of the irrigation system in the Moche Valley in terms of these three management activities should indicate the scale of centralized management required during each stage in the development of irrigation. Predictions can be derived concerning the development of political centralization and then tested against settlement pattern data.

Examining the role of irrigation in the formation of early states requires estimates of parameters such as labor requirements of canal construction, agricultural productivity, size of social groups, and the frequency of environmental perturbations. These are difficult tasks, to say the least. I have used three principles to cope with uncertainty. First, I have tried to be clear about which aspects of the analysis are least certain. Second, I present a range of estimates, rather than one estimate. Finally, in narrowing the range of estimates, I have deliberately favored estimates that make it more difficult to disprove the hydraulic model, to avoid constructing a deliberately weak or straw-man argument.

\section{Measuring Labor Mobilization}

The first set of management activities concerns the size of the labor force mobilized to construct a canal system. The basic premise of the hydraulic hypothesis is that when canal construction required small groups, the need for central leadership was minimal and short term. However, when large groups were required for long periods, long-term centralized leadership was needed.

The crucial question is the point at which a workforce became too large for informal, ephemeral leadership. The functional-oriented population thresholds can be applied to this problem. For instance, if constructing a canal required the unified effort of no more than several hundred people, the previously described thresholds predict that only one level of administration would have been necessary (e.g., village headman). If a few thousand people were required, two levels of administration (i.e., a simple chiefdom) would have been needed. Complex chiefdom or state-level organizations would have been needed only when tens of thousands of people were involved. 
Construction labor can be estimated from the total volume of canal excavation, which is calculated by multiplying cross-section area by the length of each segment of the canal (Howard and Huckleberry 1991; Ortloff et al. 1985). Because canal cross sections become narrower toward the terminus, cross sections must be measured in segments. In cases where the canal is elevated on an aqueduct, the cross section is multiplied by the length of the aqueduct. Person-days of labor required to construct the canal can then be estimated from the number of cubic meters an individual can excavate per day. ${ }^{1}$ A difficulty index can adjust excavation rates to varying soil conditions (see Table 3 in Ortloff et al. 1985).

Although simple in theory, estimating canal and aqueduct volume is in practice difficult (Howard and Huckleberry 1991; Ortloff et al. 1985). Fortunately, labor estimates have already been calculated for six lower valley canals and $\mathrm{La}$ Cumbre Intervalley canal based on field measurements of prehistoric and modern canal cross sections (Ortloff et al. 1985: Table 4; Pozorski and Pozorski 1982:866-867). Calculation of the volume of the remaining modern canals is problematic because canal cross-section data have been published for only eight of 42 canals in the modern system, and these data are limited to the length and depth of one cross section per canal (ONERN 1973:213-220).

A rate of $1 \mathrm{~m}^{3}$ per person per day was used in this study. This is significantly less than the rate of $8 \mathrm{~m}^{3}$ per person per eight-hour day used by Ortloff and his colleagues for labor estimates of prehistoric canal construction in the Moche Valley (Ortloff et al. 1985). Based on the specific gravity of adobe clay soil, 8 $\mathrm{m}^{3}$ of soil can weigh $10,800 \mathrm{~kg}$ or approximately 12 tons (Pozorski 1976:454). In order to excavate $8 \mathrm{~m}^{3}$ of soil in an eight-hour day, a person would have to move $1,350 \mathrm{~kg}$ of soil per hour or $22.5 \mathrm{~kg}$ per minute, which is equivalent to throwing a 50 -lb basket of dirt every minute nonstop for eight hours. Although increased productivity could be achieved by teams of diggers and basket carriers, such a rate seems unattainable.

On the basis of experiments, Erasmus (1965:285) estimated that a team of men using digging sticks could move approximately $2.6 \mathrm{~m}^{3}$ of earth per person per day, significantly less than $8 \mathrm{~m}^{3}$. Thomas Pozorski used a rate of $1 \mathrm{~m}^{3}$ per day for his calculations of the labor investment in the Caballo Muerto Huacas in the Moche Valley (Pozorski 1976:454).
This rate is equal to moving $1,350 \mathrm{~kg}$ of dirt per day or $168.75 \mathrm{~kg}$ per hour (one 50-lb basket of dirt every eight minutes).

Because rates of excavation vary considerably with soil conditions, I err on the side of caution and use the lowest of the three published rates $\left(1 \mathrm{~m}^{3}\right.$ per person per day). A lower rate favors the hydraulic hypothesis rather than political models because it increases labor requirements for canal construction and, presumably, the need for centralized management. For instance, at $1 \mathrm{~m}^{3}$ person per day, 1,349 people could have constructed the prehistoric Vichansao canal in one season. At $8 \mathrm{~m}^{3}$ person per day, the number drops to 169 . The Vichansao canal was constructed in the Middle Moche phase, during which the Southern Moche state formed.

Labor estimates were standardized in terms of person-seasons. There are two agricultural seasons in the Moche Valley (ONERN 1973:225). Like most other central Andean coastal valleys, a majority of the river flow occurs during the first season between December and May (Gillin 1945; Hatch 1976; ONERN 1973:225). During the second season only a fraction of the valley can be planted because of the low volume of river flow. Because considerable surplus labor is available in the second season, most canal construction probably took place then. A person-season, therefore, is a useful unit for calculating labor estimates for canal construction. A person-season equals 156 working days, based on six working days per week during the six-month season of the second crop. Based on $1 \mathrm{~m}^{3}$ per person per day, the amount of earth moved in an average person-season is $156 \mathrm{~m}^{3}$.

The next crucial parameter is the size of the social group from which labor was recruited for canal construction. If a group of households wished to construct a canal, they needed a certain number of able-bodied adults. Stated in another manner, if leaders wished to construct one of the canals, they would have needed to unify or control a social group of a certain size. The population from which the labor force was drawn was estimated using a ratio of one adult male to five other people in the population (Hassan 1981:73). If women were involved in canal construction, the social group supplying labor could have been smaller. Once again, I chose to err on the side of caution and favored the hydraulic hypothesis by considering only men and thus inferring a larger source population. 


\section{Measuring Canal User-Group Size}

The second set of management activities concerns the number of people integrated by a single canal. The people tilling the land irrigated by a canal are tied together by sharing that lifeline. If the canal is going to continue to sustain the group, the canal must be regularly maintained, land and water allocated, and disputes among the users mediated. The basic premise of the hydraulic model is that the larger the canal user group, the greater the need for central management.

By using published data on the area irrigated by canals (Moseley and Deeds 1982:Table 2.1; ONERN 1973:213-220; Ortloff et al. 1985:Table 4) and crop yields for each period (Billman 1989; Pozorski 1976, 1980; Wilson 1988:326), the maximum population supported by each canal can be calculated. These calculations, however, should take into account fallowing. During the prehistoric era, crop rotation and fallowing were probably necessary to prevent soil depletion. Modern farmers in the Moche Valley apply between 160 and $600 \mathrm{~kg}$ of fertilizer per hectare of corn depending on the "economic power" of the farmer (ONERN 1973: 161-166). Traditional farmers in the town of Moche sustained yields without the use of fertilizers by fallowing and rotating the planting of nitrogen-fixing plants such as beans, lentils, and alfalfa (Gillin 1945:15). Fallow periods were short, usually one year or one-half years, and livestock were pastured in the fields. If Gillin's observations are correct, approximately 30 percent of the fields would have been fallow during the prehistoric era. ${ }^{2}$ Because there is much uncertainty about fallowing on the coast in the prehistoric era, I use two estimates for population supported by canals. One is based on cultivation of 100 percent of the land; the other is based on annually fallowing 30 percent.

\section{Water Allocation and Mediating Disputes among Canal User Groups}

The third set of management activities deals with dispute resolution and water allocation. Unlike the two previous activities, which concern the management of individual canals, these activities involve disputes between canal user groups over water. The annual volume of the Moche River is highly variable. Based on a modern 40-year record of river flow, sufficient water for the cultivation of corn on all 20,888 ha of arable land in the valley is available only 14 out of 40 years (Billman 1996:41, 1997:293). Consequently, only as the canal system approached the limits of available water would dispute resolution and water allocation have presented problems. Disputes inevitably would have arisen between middle valley and lower valley irrigators. Because middle-valley irrigators draw off water before it reaches the lower valley, in drought years there may have been little left for lower-valley farmers. One means of coping with frequent shortages is the creation of a centralized administration to allocate water, monitor water distribution, and resolve disputes. The hydraulic hypothesis, therefore, predicts that as demand approached the limits of the water supply, centralized political organizations should have formed.

The point at which agricultural demand approached the limits of the water supply in the Moche Valley can be estimated by calculating the water requirements of agricultural production at each stage in the expansion of irrigation. The first step was to estimate the area under cultivation during each stage of development. Next, the modern 40-year record of river flow and the water requirements for corn (ONERN 1973:183, 229) were used to estimate the frequency of water shortages during each stage. The use of modern river flow records is problematic; however, local prehistoric proxy records of river flow do not exist. In absence of a local proxy record, I use the modern 40 -year record. ${ }^{3}$

\section{Testing Irrigation Theories of the Origins of the State in the Moche Valley}

Having established methods for measuring three crucial aspects of the managerial requirements of irrigation, the history of agricultural expansion in of the Moche Valley must be outlined. Agriculture was first used in the valley in the Late Preceramic period (Pozorski and Pozorski 1979a). Crops are believed to have been grown in sunken fields along the coast and on the floodplain of the river. In those areas crops may not have required canal irrigation, instead deriving water from the water table (Gillin 1945:16; Moseley and Deeds 1982; Pozorski and Pozorski 1979a).

By the start of the Guañape phase, farmers turned to intensive irrigation. The irrigation system of the valley continued to expand for the next 3,100 years, reaching a peak in the A.D. 1200s or 1300s (Moseley and Deeds 1982). Several studies have been undertaken of the expansion of prehistoric irrigation 
Table 1. Stages of the Development of Irrigation in the Moche Valley, Local Chronological Phases, and Regional Time Periods.

\begin{tabular}{|c|c|c|c|}
\hline$\underline{\text { Stage of Irrigation }}$ & Local Phase & Time Span & Regional Time Period \\
\hline $\begin{array}{l}\text { Stage } 4 \text {, far north side of the lower } \\
\text { valley reclaimed and La Cumbre }\end{array}$ & Late and Middle Chimu & A.D. $1000-1470$ & $\begin{array}{l}\text { Late Intermediate } \\
\text { period }\end{array}$ \\
\hline \multirow[t]{2}{*}{ Intervalley canal constructed } & Early Chimu & A.D. $900-1000$ & $\begin{array}{l}\text { Middle horizon/Late } \\
\text { Intermediate period }\end{array}$ \\
\hline & Late Moche & A.D. $800-900$ & \\
\hline
\end{tabular}

Stage 3, most of the north side of the lower valley

reclaimed

Stage 2, south side of the lower valley reclaimed

$\begin{array}{lll}\text { Middle Moche } & \text { A.D. } 400-800 & \\ \text { Early Moche } & \text { A.D. } 200-400 & \begin{array}{l}\text { Early Intermediate } \\ \text { period }\end{array} \\ \text { Gallinazo } & \text { A.D. } 1-200 & \\ \text { Late Salinar } & 200-1 \text { B.C. } & \\ \text { Early Salinar } & 400-200 \text { B.C. }\end{array}$

Late Guañape

Middle Guañape $\quad 1300-800$ B.C.

and 1 , middle valley

of the lower

valley reclaimed

\begin{tabular}{|c|c|c|c|}
\hline $\begin{array}{l}\text { Floodplain and } \\
\text { sunken field }\end{array}$ & $\begin{array}{l}\text { Late Preceramic } \\
\text { period }\end{array}$ & 2500-1800 B.C. & $\begin{array}{l}\text { Late Preceramic } \\
\text { period }\end{array}$ \\
\hline
\end{tabular}

period

period

Note: Very few radiocarbon dates are available for the Moche Valley. Consequently, dates for the phases in this table are in many cases highly speculative. For instance, no reliable radiocarbon dates exist for the Salinar or Gallinazo phases in the Moche Valley. Furthermore, recent dates from the site of Moche indicate that it was still occupied into the late A.D. 700s (Chapdelaine 1998:111-114; Chapdelaine et al. 2001:370), which suggests the Middle Moche phase may extend as late as A.D. 800 , pushing the start of the Early Chimu phase forward as much as 200 years.

in the Moche Valley using data from pedestrian surveys and test excavation of prehistoric canal segments (Billman 1996; Farrington 1974; Moseley and Deeds 1982; Pozorski 1987). These studies indicate that irrigation passed through four distinct stages of development (Table 1). Each of these stages represented a significant increase in managerial requirements. Changes in managerial requirements in each of the four stages can be used to test the hydraulic hypothesis in the Moche Valley.

\section{Stage 1, Guañape Phase (ca. 1800-400 B.C.)}

Irrigation in the Early Guañape phase began in the middle Moche Valley - as indicated by a dramatic shift in population there from the coast (Billman 1996:164-167)—and then expanded into the lower valley in the Middle and Late Guañape phases (Billman 1996:158; Farrington 1985:Figure 3a; Moseley and Deeds 1982:35-36; Pozorski and Pozorski 1979a). The middle valley is by far the easiest section to irrigate. It is currently irrigated by 33 short canals, ranging from .6 to $7.3 \mathrm{~km}$ in length (Figure 2) (ONERN 1973:214). Only four are longer than $3.7 \mathrm{~km}$. Canal length in the middle valley is dictated by topographic factors, such as the narrowness of the middle valley and the topography of the foothills of the Andes. Because these factors do not appear to have changed significantly, the current irrigation system serves as a useful model for estimating the labor requirements of the prehistoric canals.

Canal cross-section data have been published on only three modern middle valley canals: Quirihuac, $7.0 \mathrm{~km}$; Catuay, $5.5 \mathrm{~km}$; and Poroto, $3.7 \mathrm{~km}$ (Figure 2) (ONERN 1973:214-216). These canals are the second-, fourth-, and fifth-longest canals, respectively, and thus provide some insight into labor requirements for the longest canals. The secondlongest canal (Quirihuac) has average dimensions of only 1.25 to $1.50 \mathrm{~m}$ wide by .30 to $.40 \mathrm{~m}$ deep (ONERN 1973:216) for a total volume of excavation of approximately $4200 \mathrm{~m}^{3}$. Consequently, a workforce of approximately 27 men could have constructed the canal in one season $\left(4200 \mathrm{~m}^{3} / 156 \mathrm{~m}^{3}\right.$ per man per season). Based on a ratio of one adult male to five people, a social group of less than 150 people could have easily mustered a workforce of that size.

Although this seems like a surprisingly small 


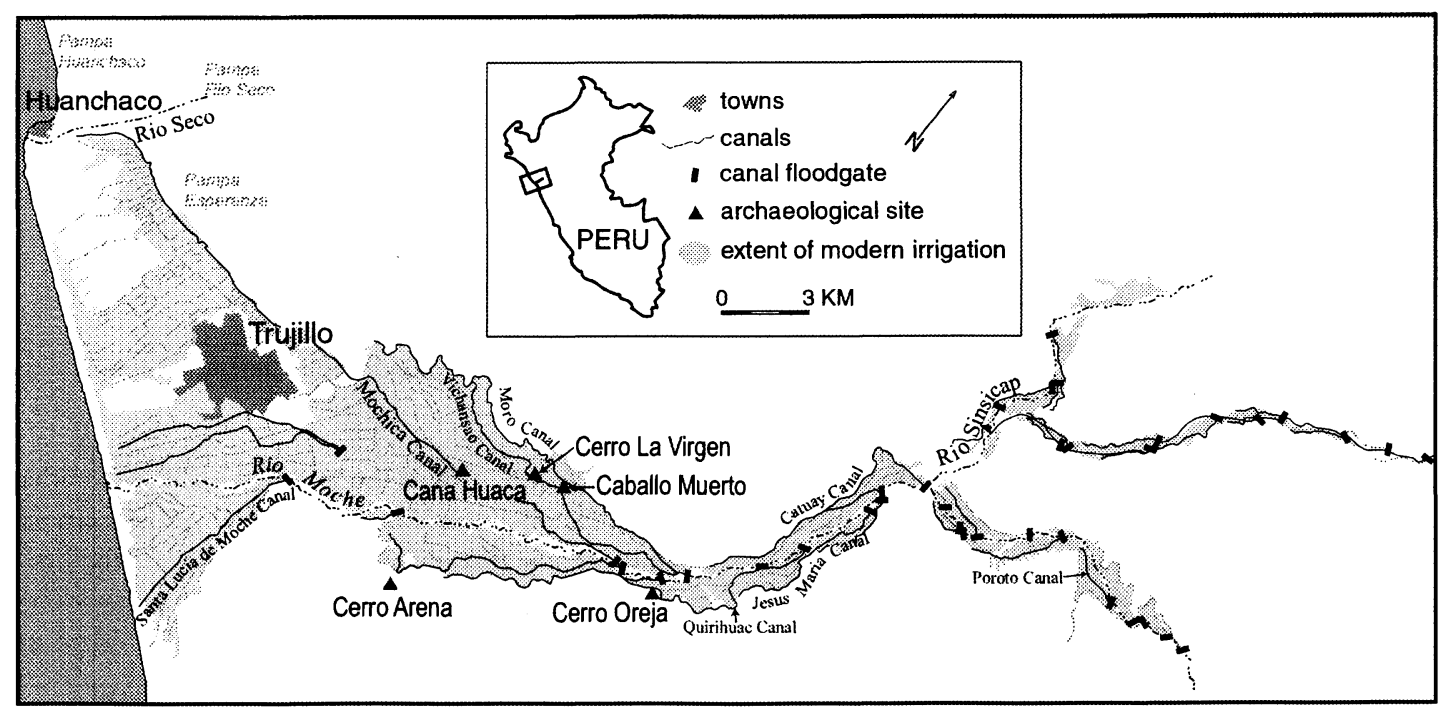

Figure 2. Locations of modern irrigation canals and key archaeological sites in the Moche Valley, Peru (adapted from Map \#6 in ONERN 1973). The middle valley currently is irrigated by 33 small canals, whereas the lower valley is irrigated by only nine canals. In the Middle Moche phase, the Vichansao canal continued to the Rio Seco; in the Late Intermediate period, it was extended onto Pampas Rio Seco and Huanchaco. Also in that period, La Cumbre Intervalley canal joined the Vichansao canal on Pampa Esperanza.

workforce, the rate of excavation expressed in terms of linear meters of canal excavation is an average of only $1.7 \mathrm{~m}$ per person per day. The workforce could have been even smaller if the canal was constructed over several seasons. Likewise, if the workforce included women and adolescents rather than just adult men, a social group with less than 150 people could have constructed the canal. The longest modern canal, Jesus María, is only slightly longer, with a length of $7.3 \mathrm{~km}$.

The Poroto canal is the fifth-longest canal in the middle valley (ONERN 1973:214-216). It could have been constructed in one season by a workforce of only 21 men drawn from a social group of approximately 105 people. Twenty-eight canals in the middle valley are even smaller than the Poroto canal. This underscores the attraction of the middle valley to early farmers; small groups could have constructed canals in one season with very modest labor.

Once completed, middle valley canals also would have supported relatively small user groups. The area irrigated by modern canals ranges from 7 to 286 ha, for an average of $68 \mathrm{ha}$. Analysis of crop productivity in the Guañape phase indicates that a hectare of irrigated land on the coast probably supported two people per year with single cropping (Billman 1989;
Pozorski 1976, 1980; Wilson 1988:326). Therefore, the largest canal in the middle valley had a potential maximum population of less than 600 people or 420 people if fallowing is considered. The average maximum population per canal was less than 140 (less than 100 with fallowing). Many canals would have supported only a few families.

In the Middle and the Late Guañape phases, irrigation expanded into the lower valley; however, cultivation was limited to easily irrigated areas adjacent to the river (Farrington 1974; Moseley and Deeds 1982; Pozorski 1976, 1980). The extent of irrigation on the north side of the river can be estimated based on the locations of the two ceremonial centers: Caballo Muerto and Caña Huaca (Figure 2). Farrington (1974, 1985:Figure 3a) and Moseley and Deeds (1982:35-36) proposed that two or three canals were constructed on the north side of the lower valley in this phase. Two would have closely followed the initial segments of the modern Mochica and Vichansao canals (Figure 2). They would have been approximately $7 \mathrm{~km}$ long, and each would have irrigated perhaps 450 ha. In addition, Moseley and Deeds (1982:35-36) suggest that portions of the Moro canal may have been constructed up to Caballo Muerto. This canal would have been about $7 \mathrm{~km}$ long 
Table 2. Estimates of the Frequency of Prehistoric Shortfalls of Irrigation Water.

\begin{tabular}{|c|c|c|c|}
\hline $\begin{array}{l}\text { Time } \\
\text { Period } \\
\end{array}$ & $\begin{array}{c}\text { Hectares } \\
\text { of Land under } \\
\text { Cultivation }\end{array}$ & $\begin{array}{c}\text { Number of } \\
\text { Shortfalls of } \\
\text { Water every } \\
40 \text { years }^{\mathrm{a}}\end{array}$ & $\begin{array}{c}\text { Number of } \\
\text { Shortfalls every } \\
40 \text { years if } 30 \% \\
\text { of land fallow }\end{array}$ \\
\hline Guañape Phase & 4,100 & 1 & 0 \\
\hline Salinar Phase & $6,750-7,300$ & $4-5$ & 2 \\
\hline Middle Moche Phase & $12,550-13,200$ & $12-14$ & 6 \\
\hline Late Intermediate Period & 19,665 & 25 & 15 \\
\hline
\end{tabular}

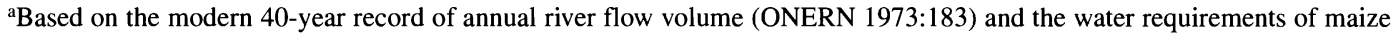
cultivation (ONERN 1973:229).

and irrigated an additional 400 ha. Although these three lower valley canals would have been similar in length to the middle valley Quirihuac canal, they each would have irrigated nearly twice as much land and, therefore, would have carried twice as much water. Consequently, labor requirements can be estimated by doubling the volume of excavation for the Quirihuac canal. Each of these three canals could have been constructed by a workforce of approximately 54 people in one season. A social group of 270 could have easily mustered such a workforce. Each canal could have supported 800-900 people (or $560-630$ people with fallowing).

Water shortages were probably relatively rare in this period (Table 2). Most if not all of the middle valley was under cultivation, and approximately 1,300 ha were cultivated on north side of the lower valley. In addition, some areas adjacent to the south side of the river also probably were irrigated; these areas totaled perhaps less than 500 ha (Farrington 1985:Figure 3a). Thus the estimated maximum extent of irrigation in the Guañape phase is 4,062 ha, which is rounded to 4,100 ha. Based on the 40 -year history of river flow, Guañape farmers rarely faced water shortages, and tension between lower and middle valley user groups would have been minimal.

In sum, Stage 1 canals could have been constructed, used, and managed by small autonomous communities. The largest canals could have been constructed by less than 60 people in one season and had user-groups of no more than 600 or 900 people. Consequently, the hydraulic hypothesis predicts that centralized political organizations should not have during the first stage of the development of irrigation in the Guañape phase (Table 3, Hypothesis 1).

\section{Stage 2, Salinar Phase (400-1 B.C.)}

In the Salinar phase, the extent of irrigation expanded significantly in the valley. By close of the phase, vir- tually all usable land in the middle valley was under cultivation (Billman 1996:202-205). In the lower valley, Salinar phase sites are found outside the limits of modern cultivation along the south side of the valley (Figure 2) (Billman 1996:195-196; Brennan 1978). One prehistoric canal also is located beyond modern cultivation; based on the dates of associated sites, this canal appears to date to the Salinar phase (Brennan 1978; Moseley and Deeds 1982). It passes by Cerro Arena, the largest Salinar phase settlement in the valley. On the north side of the valley, the only Salinar phase sites present are a large fishing village at Huanchaco and a large hilltop settlement on Cerro La Virgen (Figure 2). The latter site is located adjacent to Caballo Muerto, indicating that the Guañape phase canals were probably still in use. If other Salinar phase sites existed on the north side of the valley, they would have been destroyed by the subsequent expansion of the irrigation system.

The south side of the lower valley required more labor to irrigate than the middle valley or areas adjacent to the river on the north side of the lower valley. Currently, the south side is irrigated by four canals measuring 1.6, 8.0,10.0, and $13.0 \mathrm{~km}$ in length (ONERN 1973:214). The Santa Lucía de Moche canal is the largest modern canal on the south side and would have required approximately 327 people to construct in one season. The necessary social group would have been approximately 1,635 people. The maximum elevation prehistoric canal on the south side would have required even more labor to construct. Of course, if these canals were constructed gradually over the course of several seasons, the size of the workforce would have been greatly reduced. However, longer-term construction projects require longer-term centralized planning and coordination.

The maximum population supported by each canal also increased sharply in the Salinar phase. In addition to larger canals, an increase in agricultural pro- 
Table 3. Hypotheses, Test Implications, and Archaeological Expectations for Testing the Hydraulic Hypothesis.

Hypothesis
Hypothesis 1:
Centralized political organizations
should not have formed in the
Guañape phase during the first
stage of the development of irriga-
tion. Canals could have been con-
structed, used, and managed by
small autonomous communities or
villages (community-level politi-
cal integration).

cal integration).

\section{Test Implications \\ Guañape phase polities in the} valley did not (1) integrate numerous villages, (2) contain several levels of administrative hierarchy, (3) extract quantities of tribute from surrounding villages, and (4) legitimize political authority by the construction of public monuments.

Archaeological Expectation
Archaeological Expectation 1.1, Settlement
Hierarchies: Site-size hierarchies should not exist in the
valley during the Guañape phase.

Archaeological Expectation 1.2, Settlement Location: Sites located at central places should not be significantly larger than surrounding sites with similar catchment productivity. Small sites should not be clustered around large sites.

Archaeological Expectation 1.3, Catchment Productivity: The population of large sites should not exceed the productive resources within the site catchment area.

Archaeological Expectation 1.4, Public Architecture: Public architecture should be absent or limited in scope in during the Guañape phase. If present, the architecture should not have required significant quantities of labor input to construct.
Salinar phase polities in the valley should have (1) integrated several villages, (2) contained two levels of administrative hierarchy, (3) extracted quantities of tribute from surrounding villages, and (4) legitimized political authority by the construction of medium-sized public monuments.

Archaeological Expectation 2.1, Settlement Hierarchies: Two levels of site-size hierarchy should exist in the valley during the Salinar phase.

Archaeological Expectation 2.2, Settlement Location: Sites located at central places should be significantly larger than surrounding sites with similar catchment productivity. Small sites should be clustered around large sites.

Archaeological Expectation 2.3, Catchment Productivity: The population of large sites should exceed the productive resources within the site catchment area.

Archaeological Expectation 2.4, Public Architecture: Medium-sized public architecture should be present in the valley during the Salinar phase.

A polity should have developed in the Middle Moche phase that (1) integrated most of the settlements in the valley, (2) contained more than two levels of administrative hierarchy, (3) extracted large quantities of tribute from villages throughout the valley, and (4) legitimized political authority by the construction of large public monuments.
Archaeological Expectation 3.1, Settlement

Hierarchies: A site-size hierarchy with three or more levels should not exist in the Moche Valley until the Middle Moche phase.

Archaeological Expectation 3.2, Settlement Location: During the Middle Moche phase, large sites should have formed at central places in the valley. Smaller sites should be clustered around the large sites.

Archaeological Expectation 3.3, Catchment Productivity: The population of large sites should greatly exceed the productive resources within the site catchment area. 
Table 3. Hypotheses, Test Implications, and Archaeological Expectations for Testing the Hydraulic Hypothesis (continued).

\begin{tabular}{|c|c|c|}
\hline Hypothesis & Test Implications & Archaeological Expectation \\
\hline & & $\begin{array}{l}\text { Archaeological Expectation 3.4, Public Architecture: } \\
\text { Large-scale public architecture should not be present in } \\
\text { the Moche Valley until the Middle Moche phase. } \\
\text { Middle Moche phase public architecture should have } \\
\text { required large quantities of labor drawn from the entire } \\
\text { valley. }\end{array}$ \\
\hline
\end{tabular}

Hypothesis 4:

Complex, regional political organizations should not have emerged until the Late Intermediate period during the fourth stage of the development of irrigation. Canal construction, use, and management involved more than one river valley (political integration of multiple valleys).
A polity should have developed in the Late Intermediate period that (1) integrated several valleys, (2) contained more than three levels of administrative hierarchy, (3) extracted large quantities of tribute from villages throughout the valley and adjacent valleys, and (4) legitimized political authority by the construction of massive public monuments.
Archaeological Expectation 4.1, Settlement Hierarchies: A region-wide system of administrative centers with multiple levels of control should not have developed on the north coast until the Late Intermediate period.

Archaeological Expectation 4.2, Settlement Location: During the Late Intermediate period, large sites should have formed at central places on the north coast.

Archaeological Expectation 4.3, Catchment Productivity: The population of the paramount center should exceed the productive resources within the Moche Valley.

Archaeological Expectation 4.4, Public Architecture: Large-scale public architecture requiring labor from beyond the Moche Valley should not be present until the Late Intermediate period. Late Intermediate period public architecture should have required massive quantities of labor to construct. ductivity is indicated by increased corncob length. Wilson estimates Salinar phase productivity at 2.6 people per ha (Wilson 1988:326). Therefore, the largest modern canal on the south side could have supported a maximum population between 1,942 and 2,774 , and the average per canal on the south side was between 918 and 1,391. Estimates of the area irrigated by the prehistoric maximum elevation canal on the south side of the valley range from 650 (Farrington 1985:638) to 1,200 ha (Moseley and Deeds 1982:Figure 2.1), which would mean a canal user group of between 1,690 to 3,120 people or 1,183 to 2,184 people with fallowing. These figures indicate that the largest user group in the Salinar phase was 2 to 3.5 times the size of the largest Guañape phase user group.

An estimate of land potentially under cultivation in the Salinar phase can be obtained by totaling the middle valley area-2,262 ha (ONERN 1973: 154-155) - the maximum extent of prehistoric cultivation on the south side of the lower valleybetween 3,200 and 3,750 ha (Moseley and Deeds 1982: Table 2.1) —and an estimate of the area of cultivation on the north side of the lower valley $-1,300$ ha (Moseley and Deeds 1982). The resulting total of 6,762 to 7,312 ha was rounded to 6,750 and 7,300 ha. The amount of water required to irrigate that much land indicates that, when the south side of the lower valley was reclaimed in the Salinar phase, water shortages began to occur with some degree of frequency (Table 2). Several shortfalls in irrigation water would have occurred during a person's lifetime. These water shortages would have led to serious disputes between lower and middle valley canal user groups.

In short, in Stage 2, the size of construction workforces and user groups grew significantly. Canal projects would have required labor from multiple villages; single canals would have sustained multiple communities. Water shortages probably began to occur several times a generation, creating tensions between middle and lower valley user groups. Consequently, the hydraulic hypothesis predicts that irrigation would have required two levels of political control. Simple centralized political organizations should have first developed in the Salinar phase during the second stage of the development of irrigation (Table 3, Hypothesis 2). 


\section{Stage 3, Moche Phase (A.D. 200-900)}

No significant expansion of the irrigation system has been identified for the Gallinazo and Early Moche phases. The area of irrigation in the lower valley actually may have declined as population shifted to the middle valley (Billman 1996:247-250). Cerro Arena in the lower valley was completely abandoned at the close of the Salinar phase, and the population of Cerro La Virgen declined dramatically in the Gallinazo phase (Figure 2).

During the Middle Moche phase, the first truly large-scale canals were constructed when irrigation expanded into the far reaches of the north side of the valley, which is the most difficult area to reclaim (Figure 2). Large areas of arable land were opened up on the north side on the Pampa Esperanza through the expansion of the Moro, Vichansao, and Mochica canals (Figure 2) (Moseley and Deeds 1982:37-42). Because those canals carried much more water than the segments in use in the Guañape and Salinar phases, it would have been necessary to rebuild them. Dating their construction is particularly important, because the Southern Moche state formed in this phase. Various researchers date this burst of canal construction to the Middle Moche phase (Farrington 1974:85, Figure 8.3; Moseley and Deeds 1982:39-42; Pozorski 1987:113). Numerous Moche phase sites have been recorded on Pampa Esperanza along all three canals. Ceramics from those sites include only Moche III and IV diagnostics; no Early Moche, Gallinazo, or Salinar phase sites have been identified.

The Mochica canal has the lowest elevation of these three canals and probably was constructed first (Figure 2). In the Middle Moche phase, it was extended all the way to the Rio Seco, with a terminus somewhere near Huanchaco, opening up a large portion of Pampa Esperanza. Twice in the Middle Moche phase, a segment of the canal on the pampa was moved northward to progressively higher elevations in order to increase the area of cultivation (Moseley and Deeds 1982:42, Figure 2.2 and 2.3). In the Moche phase, the Mochica canal was unlined and approximately $31 \mathrm{~km}$ long, a truly monumental construction (Ortloff et al. 1985:82). Pozorski (1987:Table 1) cites one uncalibrated radiocarbon date of A.D. $550 \pm 80$ for the extension of the Mochica canal onto Pampa Esperanza, which suggests construction sometime between A.D. 436-779 (calibrated with two sigmas ${ }^{4}$ ). Given the presence of Moche III diagnostics on the pampa, this places construction after A.D. 400 in the early part of the Middle Moche phase.

Later in the Middle Moche phase, the Moro canal was expanded. Although the modern Moro canal does not extend all the way to Pampa Esperanza, Ortloff, Feldman, and Moseley proposed that in the Middle Moche Phase it extended $28 \mathrm{~km}$ all the way to Pampa Esperanza and would have irrigated a large stretch of land above the Mochica canal (Figure 2) (Ortloff et al. 1985:79). Further, they postulated that the canal was constructed in Moche IV, sometime before a major El Niño between A.D. 450 and 600 (Ortloff et al. 1985:79, 91).

Portions of the Moro canal on Pampa Esperanza were eventually replaced by the Vichansao canal, which was constructed at an even higher elevation, opening up most of the remaining arable land on the pampa (Figure 2). Moseley and Deeds note that the Vichansao canal cut through a Moche III cemetery, but did not cut through any of the numerous Moche IV sites along the canal, placing the construction of the canal in the later part of the Middle Moche phase (Moseley and Deeds 1982:37). The Moche phase canal would have been at least $30 \mathrm{~km}$ long (Ortloff et al. 1985:81).

Whereas the largest Salinar phase canals required 300-400 person-seasons to construct, the Middle Moche phase Moro, Mochica, and Vichansao canals required approximately 500, 600, and 900 personseasons to complete, respectively (Ortloff et al. 1985:Table 4). In other words, the Vichansao canal required more than twice the labor of any other canal previously constructed in the valley. Because of its size, the Vichansao probably was constructed over several years by a workforce of hundreds of people. Leaders would have had to mobilize or control large groups for several years. For instance, if the canal was constructed in one year, the social group from which labor was drawn would have numbered approximately 4,500 ; if constructed over five years, the social group would have been 900 people.

Canal user groups also would have been massive, even though corn yields appear to have remained approximately the same as in the Salinar phase (Wilson 1988:326). The Moro canal could have supported 2,243 people (1,570 with fallowing) (Moseley and Deeds 1982:Table 2.1). The modern extent of the Mochica canal is approximately equal to its extent 
in the Moche phase. Currently it irrigates 4,850 ha (ONERN 1973:214) and could support 12,610 people (8,827 with fallowing).

With the dramatic increase in cultivated land in the Middle Moche phase, water shortages would have occurred regularly. Altogether between 12,538 and 13,188 ha were under irrigation in the Moche Valley by the end of the Middle Moche phase. ${ }^{5}$ Based on the modern record of river volume, irrigation water shortages would have occurred 12 to 14 times in 40 years (Table 2). If 30 percent of the land was fallow, shortages would have occurred six times every 40 years. Disputes between lower and middle valley canal user groups would have been a chronic problem.

Because of dramatic increases in the managerial requirements of irrigation, the hydraulic hypothesis predicts that the first valley-wide polity should have emerged in the Middle Moche phase (Table 3, Hypothesis 3). Construction of the Mochica, Moro, and Vichansao canals would have required hundreds of laborers; once in use, each canal would have supported thousands of people; and water shortages would have occurred every few years. Irrigation of the north side of the lower valley would not have been possible without some sort of centralized authority that could allocate water and mediate disputes.

\section{Stage 4, Late Intermediate Period (A.D. 1000-1470)}

During the Late Intermediate period (LIP), irrigation expanded dramatically on the far north side of the valley (Figure 2). Four major canal projects of considerable magnitude were completed by A.D. 1300, before a major El Niño event (Moseley and Deeds 1982:42-43; Pozorski 1987:112-113). First, a new version of the Moro canal was constructed adjacent to the old canal. Second, the distal end of the Vichansao canal was elevated and stone lined. Third, the Vichansao canal was extended across the Pampa Río Seco and Pampa Huanchaco, opening those areas for cultivation. And finally, La Cumbre Intervalley canal was constructed from the Chicama to the Moche Valley (Ortloff et al. 1985; Pozorski 1987; Pozorski and Pozorski 1982). All four projects were constructed over 200 to 300 years and required an extraordinary amount of labor (Ortloff 1985 et al.:Table 4). In addition, several large canals were constructed above the limits of modern cultivation in the middle Moche Valley; however, data on those canals are not available.
By far the largest of these projects was La Cumbre Intervalley canal, which was intended to bring water from the Chicama Valley to newly created fields on Pampas Río Seco and Huanchaco. The canal was over $70 \mathrm{~km}$ long, more than twice the length of any canal ever constructed in the Moche Valley. Labor estimates for its construction vary greatly from more than $700,000,000$ person-hours (or 560,900 personseasons) (Ortloff et al. 1985:Table 4) to 4,143,647 person-days (or 26,561 person-seasons) (Pozorski and Pozorski 1982:866). Based on their analysis of an abortive canal segment located adjacent to the canal, Pozorski and Pozorski (1982:866) further proposed that the typical workforce consisted of approximately 1,000 people. A workforce of that size could have completed the canal in 26 years, or a generation. In other words, the construction of La Cumbre Intervalley canal required nearly 30 times the amount of labor of the largest Middle Moche phase canal in the Moche Valley.

The most dramatic rise in population per canal was in the LIP when corn yields increased to 6.8 people per ha (Wilson 1988:326). The largest canal potentially could have supported between 21,807 and 33,041 people, depending on fallowing. Even the smallest canal on the north side could have supported between 1,105 and 1,579 people.

In the LIP, the area of cultivation exceeded the modern extent of irrigation on the north side of the valley (Farrington 1974; Moseley and Deeds 1982; Ortloff et al. 1985; Pozorski 1987). On the south side of the valley, 1,223 ha of land beyond the limits of modern irrigation were abandoned, possibly due to dune formation (Moseley and Deeds 1982). Consequently, the potential maximum extent of irrigation in the LIP was equal to the maximum possible extent of cultivation in the valley $(20,888 \mathrm{ha})$ minus the area of cultivation that was abandoned on the south side (1223 ha) for approximately 19,665 ha. Extension of the Vichansao canal to the Pampa Rio Seco and Pampa Huanchaco would have added even more irrigated land.

As the far reaches of the valley were reclaimed in the LIP, water shortages increased dramatically. Agricultural demand probably frequently exceeded the supply of water. Based on the modern record of river volume, 19,665 ha of land could have been irrigated only 15 out of 40 years or 25 out of 40 years if land was fallowed (Table 2). Irrigation of this quantity of land would have required regular valley-wide 
management of water in order to insure that lowervalley farmers received sufficient water. Further, the construction of La Cumbre Intervalley canal indicates that leaders controlled water allocation in both the Moche and Chicama Valleys.

In sum, another dramatic increase in managerial requirements occurred in the LIP. The size of construction work groups grew to 1,000 or more laborers, and construction would have lasted for decades on La Cumbre Intervalley canal. Some canal user groups probably exceeded 20,000 , and water shortages occurred every two or three years. For the first time, canal construction, use, and management involved more than one river valley. Consequently, the hydraulic hypothesis predicts that the first multivalley polities should not have emerged until the LIP (Table 3, Hypothesis 4).

\section{Deriving Hypotheses, Test Implications, and Archaeological Expectations}

Testing each of four proposed hypotheses for evaluating the hydraulic model involves the recognition and measurement of political centralization (Table 3). Attributes of centralized polities include hierarchical control and administration, tribute collection, and legitimation of authority. These attributes can be identified archaeologically in four ways. First, the analysis of settlement hierarchies can indicate the number of levels of administrative control in a polity and the number of communities controlled by a polity (Flannery 1998:16-21; Isbell and Schreiber 1978; Johnson 1973; Sanders et al. 1979; Wilson 1988; Wright and Johnson 1975). Second, tribute collection can be measured by comparing the size of centers to their catchment productivity (Massey 1986; Steponaitis 1981). Third, because the use of centrally located facilities reduces administrative and tribute transportation costs, political centralization also can be detected by monitoring the growth at central sites (Earle 1976; Johnson 1973; Massey 1986; Peebles 1978; Steponaitis 1978; Upham 1982). Finally, construction of public architecture is another attribute of political centralization because political leaders often use public monuments to legitimize political control and disseminate their ideology (Billman 1999; DeMarrais et al. 1996). Analysis of the design, extent, and distribution of public architecture can indicate the extent of political control and the scope of power of leaders (Billman 1999; Haas 1982, 1985, 1987; Moore 1996a, 1996b; Pozorski 1976, 1980, 1982).
These four measures of centralization were used to identify the test implications of the four hypotheses (Table 3). Four archaeological expectations then were derived for each of the test implications (Table 3). The archaeological expectations reveal that four types of settlement pattern data are needed to reconstruct the development of centralized polities the Moche Valley and to test the four hypotheses derived from management-oriented theories. Data are needed to assess the development of site hierarchies, the location and size of site clusters, the catchment productivity of regional and local centers, and the size and layout of public architecture.

Settlement pattern data from two pedestrian surveys of the Moche Valley (Figure 1) (Billman 1996) cover the coastal section and provide information on over 910 archaeological sites from the Late Preceramic period to Spanish conquest. The first survey, directed by Michael Moseley during the Chan ChanMoche Valley Project, covered the entire lower valley, and documented over 420 sites. In 1990 and 1991, I surveyed the middle valley (Figure 1) and recorded an additional 483 sites (Billman 1996). Information on early political formation is also provided by excavations at the Late Preceramic site of Alto Salaverry (Pozorski and Pozorski 1979a), the Guañape ceremonial center of Caballo Muerto (Pozorski 1976, 1980, 1982), Cerro Arena (Brennan 1978, 1980a, 1980b), and the site of Moche (Topic 1977, 1982; Uceda et al. 1997, 1998).

\section{The Formation of Centralized Polities in the Moche Valley}

A sequence of political development for the Moche Valley spanning the formation of the first autonomous village in the Late Preceramic period to the zenith of the Southern Moche state has been reconstructed (Table 1) (Billman 1996, 1997, 1999). In the latter part of the Late Preceramic period, the first large sedentary village formed at Alto Salaverry (Figure 3) (Billman 1996:99-103; Pozorski and Pozorski 1979a). The subsistence base of the inhabitants was farming and fishing. The population of Alto Salaverry numbered in the hundreds and may have had some form of social ranking as evidenced by the presence of two possible elite residences with large storage facilities (Billman 1996:104-113; Pozorski and Pozorski 1979a). A small circular sunken court may have served as some type of community center for village residents; however, there 


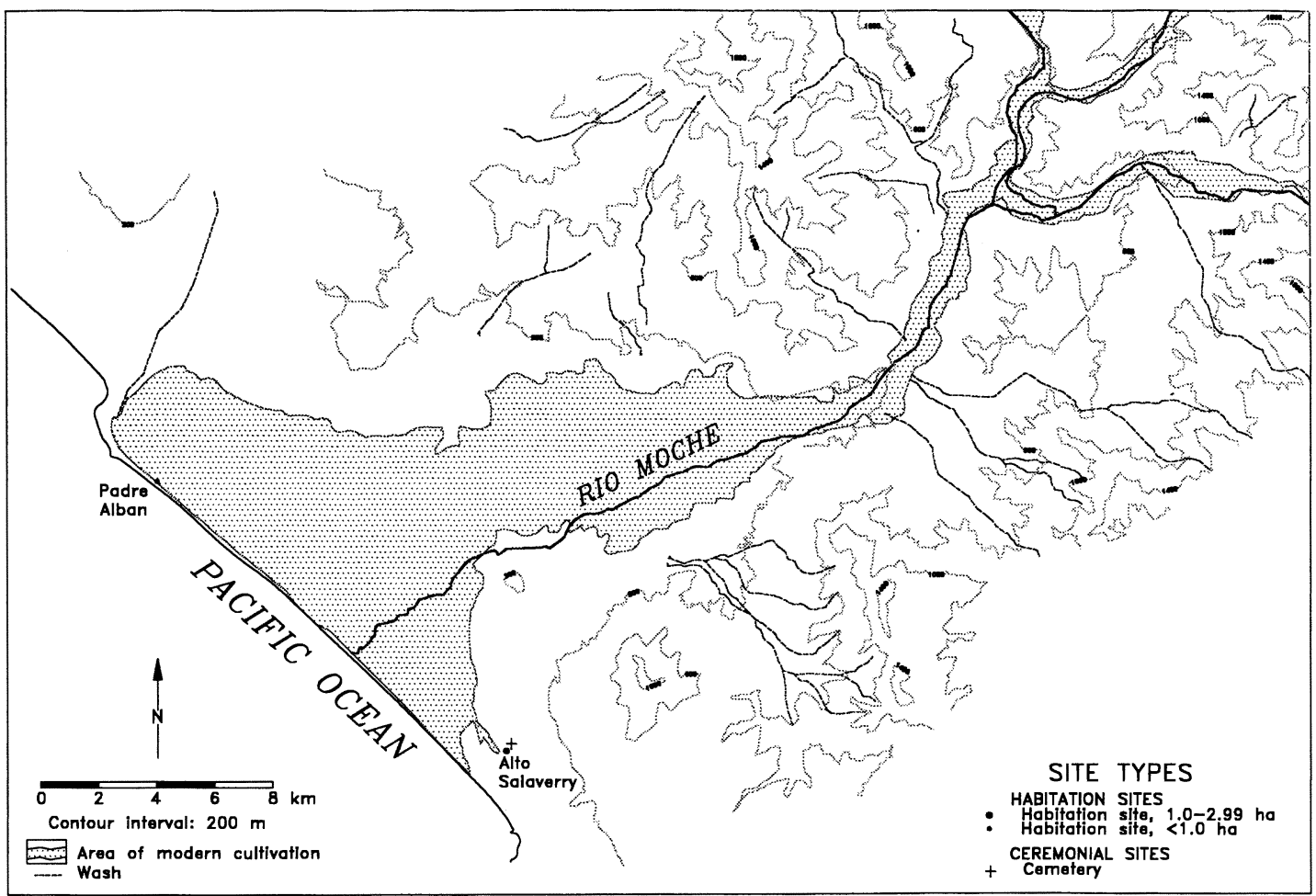

Figure 3. Location of archaeological sites dating to the Late Preceramic period, Moche Valley, Peru (2500-1800 B.C.).

is no evidence that Alto Salaverry was integrated into a multivillage polity.

\section{Guañape Phase}

In the Early Guañape phase the pattern of settlement changed radically (Billman 1996:131-182; Pozorski and Pozorski 1979b). Settlements shifted inland to the middle valley, irrigation agriculture was introduced, and over $33,000 \mathrm{~m}^{3}$ of ceremonial architecture were constructed (Figure 4). Nearly all the ceremonial architecture was concentrated at Huaca Menocucho in the middle valley with the remainder distributed among five small centers.

Investment in ceremonial architecture grew significantly in the Middle Guañape phase with the construction of between 283,000 and $318,000 \mathrm{~m}^{3}$. It was distributed between one primary center at Caballo Muerto, two secondary centers, and at least three small centers (Figure 5) (Billman 1996:141-182; Pozorski 1976, 1980, 1982). At Caballo Muerto over $231,600 \mathrm{~m}^{3}$ of ceremonial architecture were constructed, seven times the total for the entire Early Guañape phase. Most of this construction occurred in the early part of the Middle Guañape phase (Billman 1996:171-172; Pozorski 1983). By the Late
Guañape phase construction declined to between 65,000 and $100,000 \mathrm{~m}^{3}$, and no single center dominated the valley (Figure 6) (Billman 1996:155-182; Pozorski 1983).

Because of the destruction of many habitation sites by the expansion of agriculture in the prehistoric era, demographic information on the Guañape phase is limited. Fortunately, the size and design of ceremonial construction permit some inferences about the nature of political organization. The huge volume of construction indicates that leaders were able to mobilize large labor groups on a consistent basis for the construction of large public monuments. By the Middle Guañape phase, a three-tiered hierarchy of monuments developed. This hierarchy may be a manifestation of a hierarchy of leadership: paramount leaders with access to a valley-wide labor pool, a second level of leadership with a local labor pool, and a third level of village leaders (Billman 1996:205-219). The design of ceremonial architecture indicates that these monuments were used for the presentation of public displays to groups numbering in the thousands. Not all rituals, however, were open to the public. At Caballo Muerto, Huaca Los Reyes had a three-tiered hierarchy of space with 


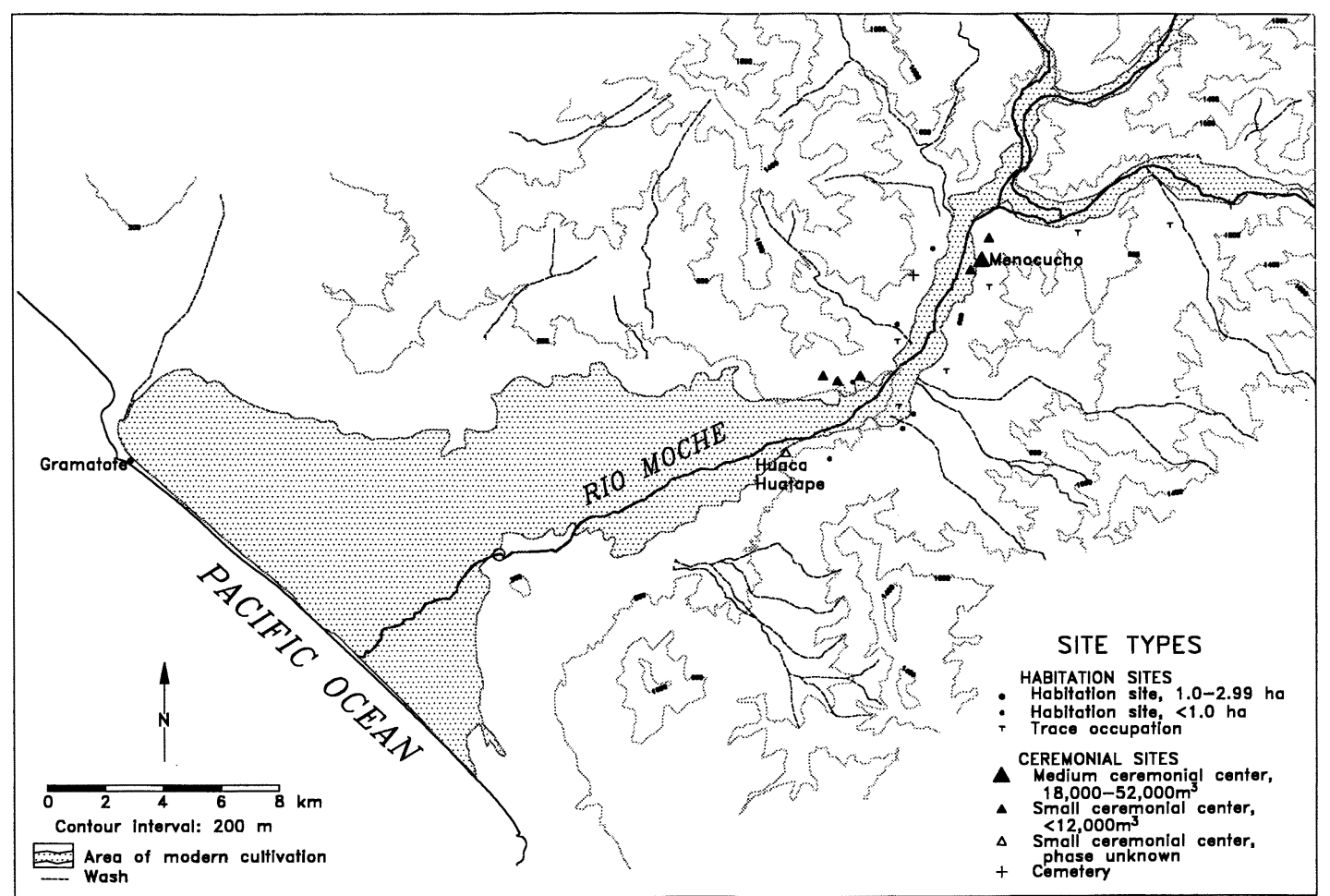

Figure 4. Location of archaeological sites dating to the Early Guañape phase, Moche Valley, Peru (1800-1300 B.C.).

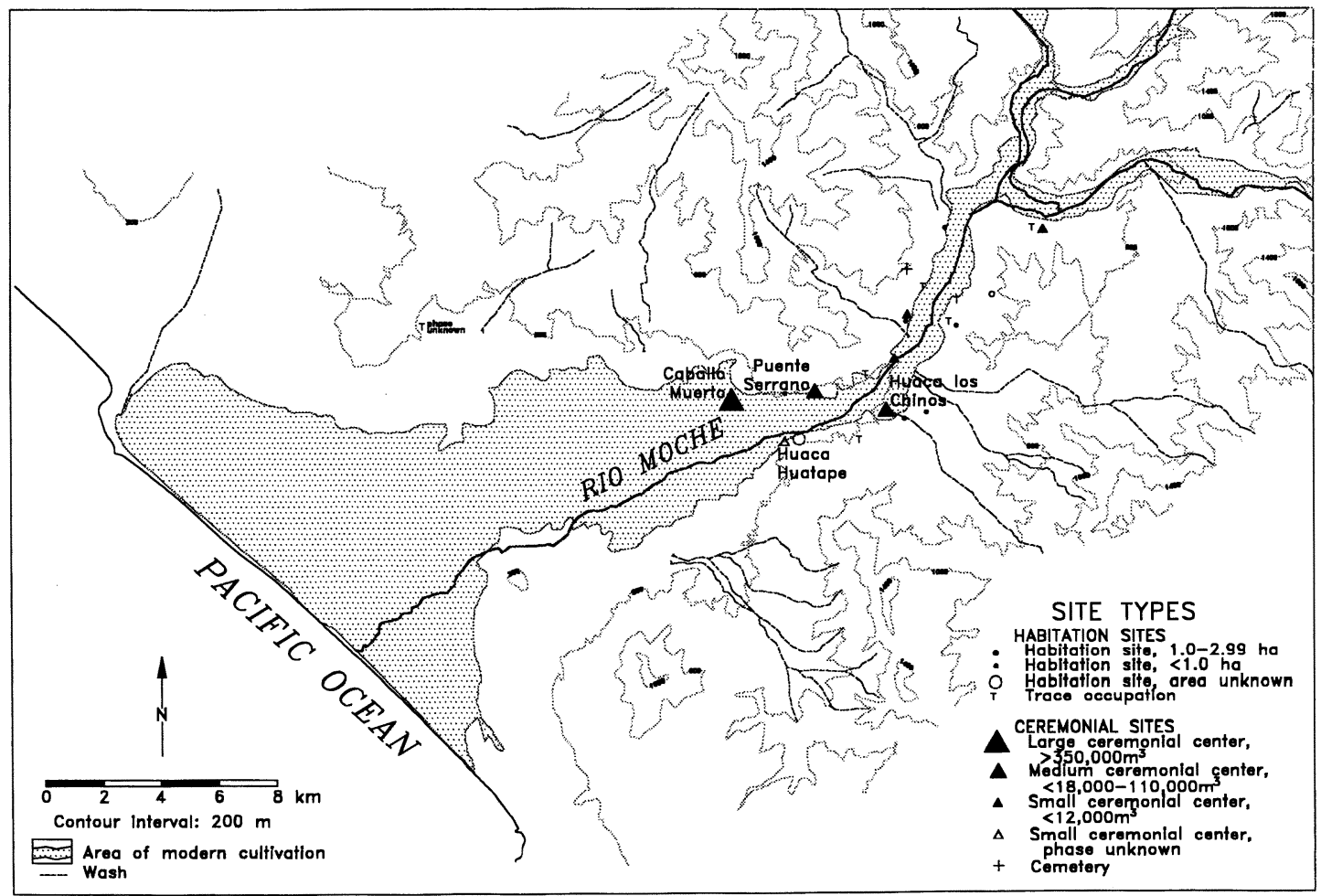

Figure 5. Location of archaeological sites dating to the Middle Guañape phase, Moche Valley, Peru (1300-800 B.C.). 


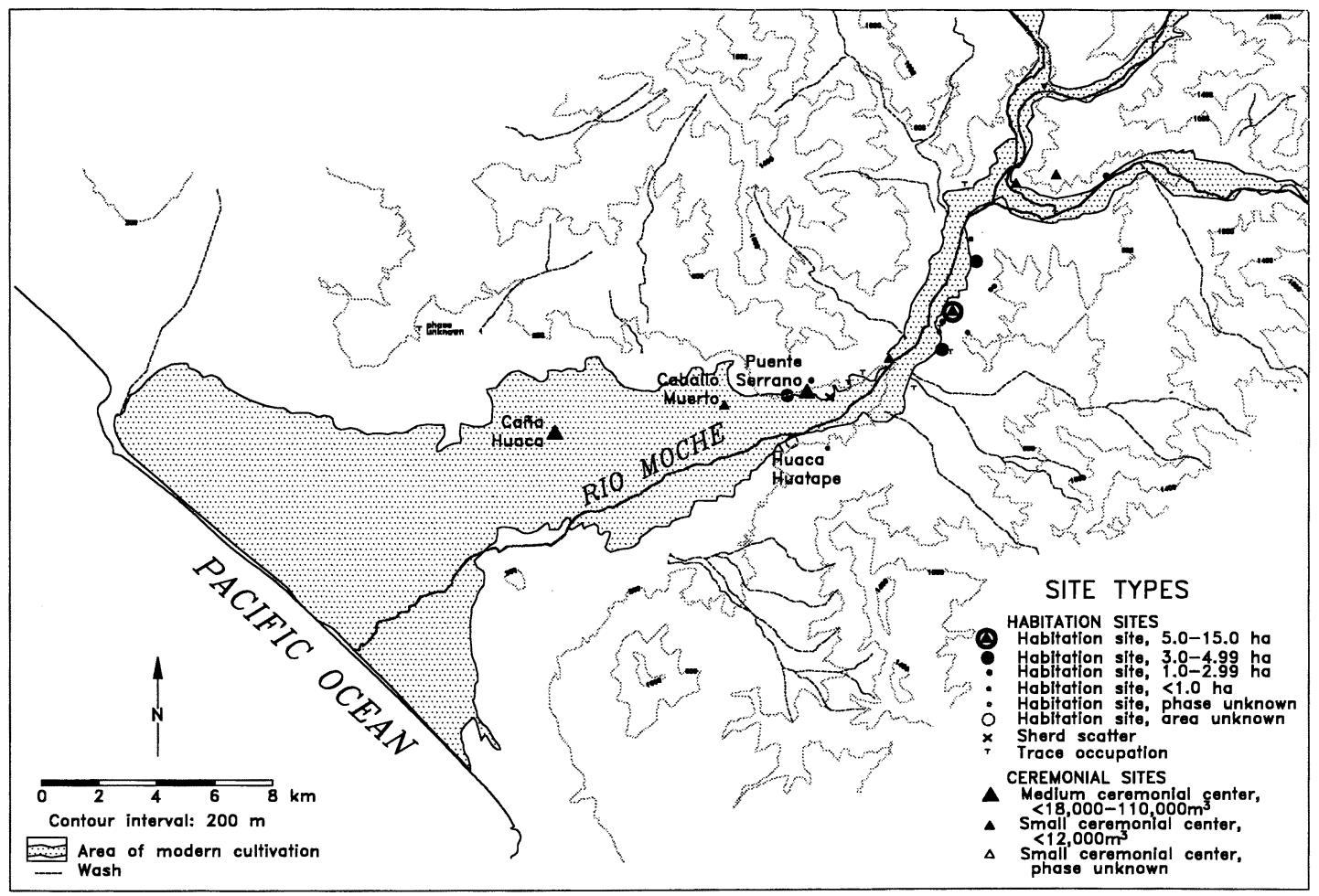

Figure 6. Location of archaeological sites dating to the Late Guañape phase, Moche Valley, Peru (800-400 B.C.).

a large public plaza, an intermediate-sized plaza on the second level of the mound, and small ceremonial spaces on top of the mound. This suggests a hierarchy of public displays and restricted access to certain ritual activities (Pozorski 1976, 1980, 1982).

Management-oriented models predict that centralized political organizations should not have developed during the first stage of irrigation in the Guañape phase (Hypothesis 1). However, analysis of settlement hierarchies and public architecture indicates that centralized political organizations did develop during this phase. A multitiered settlement hierarchy developed that encompassed all or most of the valley, and the construction of public architecture increased exponentially.

By implication, the managerial requirements of irrigation in the Guañape phase cannot explain the formation of the first valley-wide polity. Guañape phase canals did not require large labor forces to construct; they integrated relatively small groups of people, and water shortages were probably still uncommon. In short, irrigation could have been conducted without centralized political organizations.

In contrast, the managerial requirements of mon- ument construction far exceeded the requirements of canal construction. A rough estimate of the volume Guañape phase middle valley canals was derived based on the $85 \mathrm{~km}$ of 33 modern canals (ONERN 1973:214), multiplied by the average cross-sectional areas $(1.4 \times .4 \mathrm{~m})$ of the three canals with published data (ONERN 1973:214), for a total of $47,600 \mathrm{~m}^{2}$. The three lower valley Guañape canals probably had a total volume of less that $25,200 \mathrm{~m}^{3}$ (based on multiplying the estimated volume of the largest canal by three) for an overall canal volume of $72,800 \mathrm{~m}^{3}$ in that phase.

The volume of Guañape phase monumental construction is $417,000 \mathrm{~m}^{3}$, nearly six times the volume for all of the Guañape canals. The managerial requirements of constructing the Guañape monuments was roughly equivalent to constructing all the prehistoric canals on the north side of the valley $\left(504,370 \mathrm{~m}^{3}\right)$, a task undertaken by the Chimu state some 1,400 years later. Construction of all of the Middle Guañape phase monuments at the paramount center of Caballo Muerto alone involved moving $231,000 \mathrm{~m}^{3}$ of dirt, a greater volume than excavating Vichansao $\left(210,370 \mathrm{~m}^{3}\right)$, the largest prehistoric 


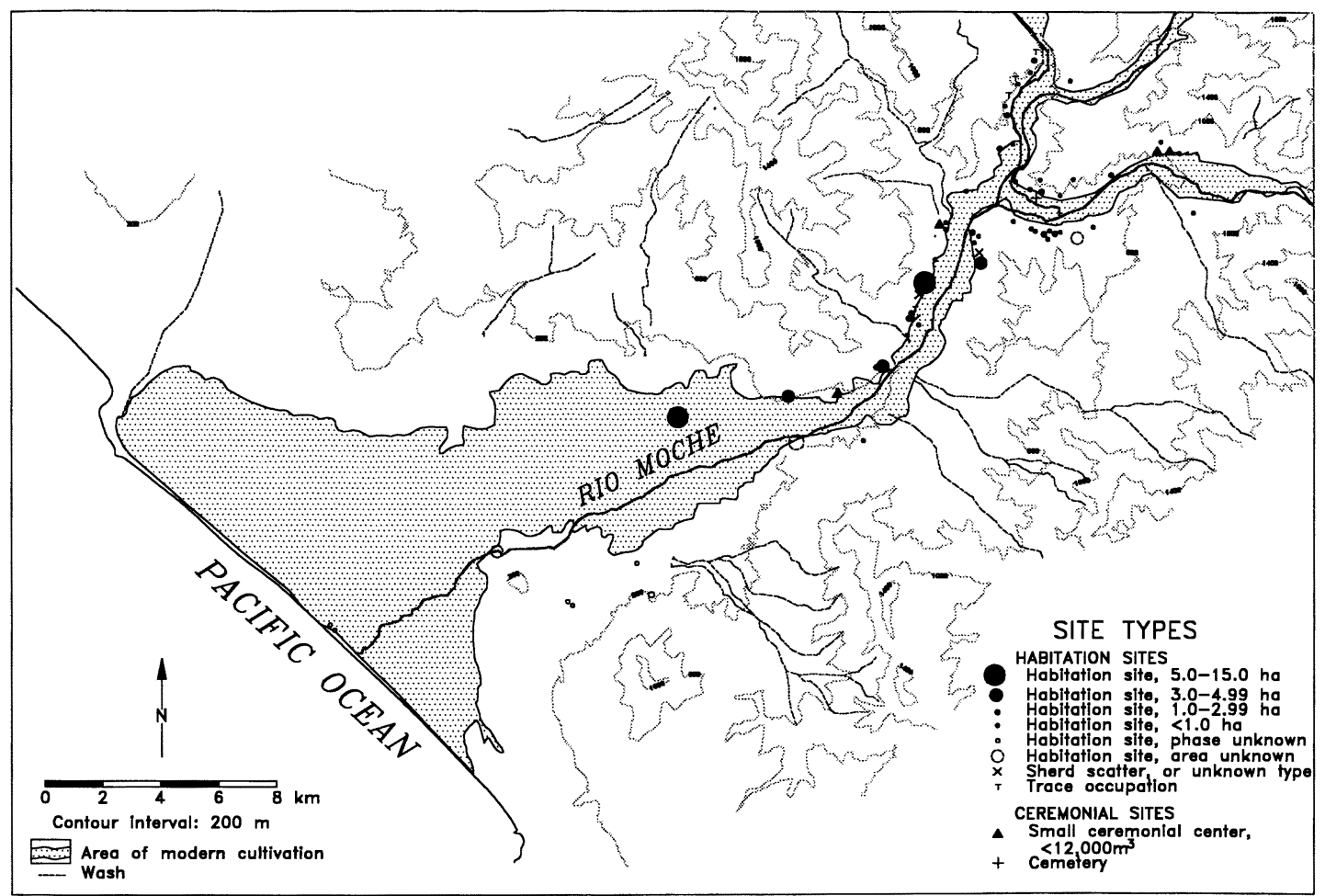

Figure 7. Location of archaeological sites dating to the Early Salinar phase, Moche Valley, Peru (400-200 B.C.).

canal, excluding the massive La Cumbre Intervalley canal. Clearly, if we wish to understand the formation of the first centralized polities in the valley, we must look beyond the managerial requirements of canal construction.

\section{Salinar Phase}

By the start of the Salinar phase, the early coastal tradition of monumental construction and associated political organizations appear to have come to an end. All of the Late Guañape phase ceremonial centers were abandoned, the population aggregated into clusters, and most habitation sites shifted to defensive settings (Figure 7) (Billman 1996:187-235). A new cycle of political formation had begun.

By the Late Salinar phase, nine distinct population clusters formed in the valley. The clusters were separated by unoccupied buffer zones (Figure 8) (Billman 1996:205-215). For instance, along the south side of the lower valley, the Cerro Arena and Cerro Oreja clusters were separated by $9 \mathrm{~km}$ of unoccupied valley margin. This occupational gap is probably not due to poor site preservation since the maximum limit of cultivation had been reached and Salinar sites were not destroyed by subsequent expansion of irrigation. In the middle valley, site clusters were separated by 1.8 to $3.9 \mathrm{~km}$ of unoccupied valley margin. The unoccupied zones contrast with densely packed habitation sites within the clusters. For example, the Puente Serrano cluster extended for less than $1 \mathrm{~km}$ along the valley margin and contained 20 ha of habitation area (Figure 8). Down valley from the edge of that cluster to the next cluster there was $3 \mathrm{~km}$ of unoccupied valley margin; up valley there was $2 \mathrm{~km}$ of unoccupied margin.

The population clusters have an internal twotiered settlement hierarchy and appear to have been politically autonomous in Early Salinar phase. In the Late Salinar phase, the clusters may have formed a loose confederation dominated by the Cerro Arena cluster (Billman 1996:213-215). With a population numbering in the thousands, the Cerro Arena cluster could have mustered more warriors than all the others combined.

Investment in public architecture dropped dramatically in the Salinar phase, declining by $70-90$ percent from between 65,000 and $100,000 \mathrm{~m}^{3}$ in the Late Guañape phase to just over $15,000 \mathrm{~m}^{3}$. New ceremonial structures accommodated small groups, had restricted access, and were often associated with elite 


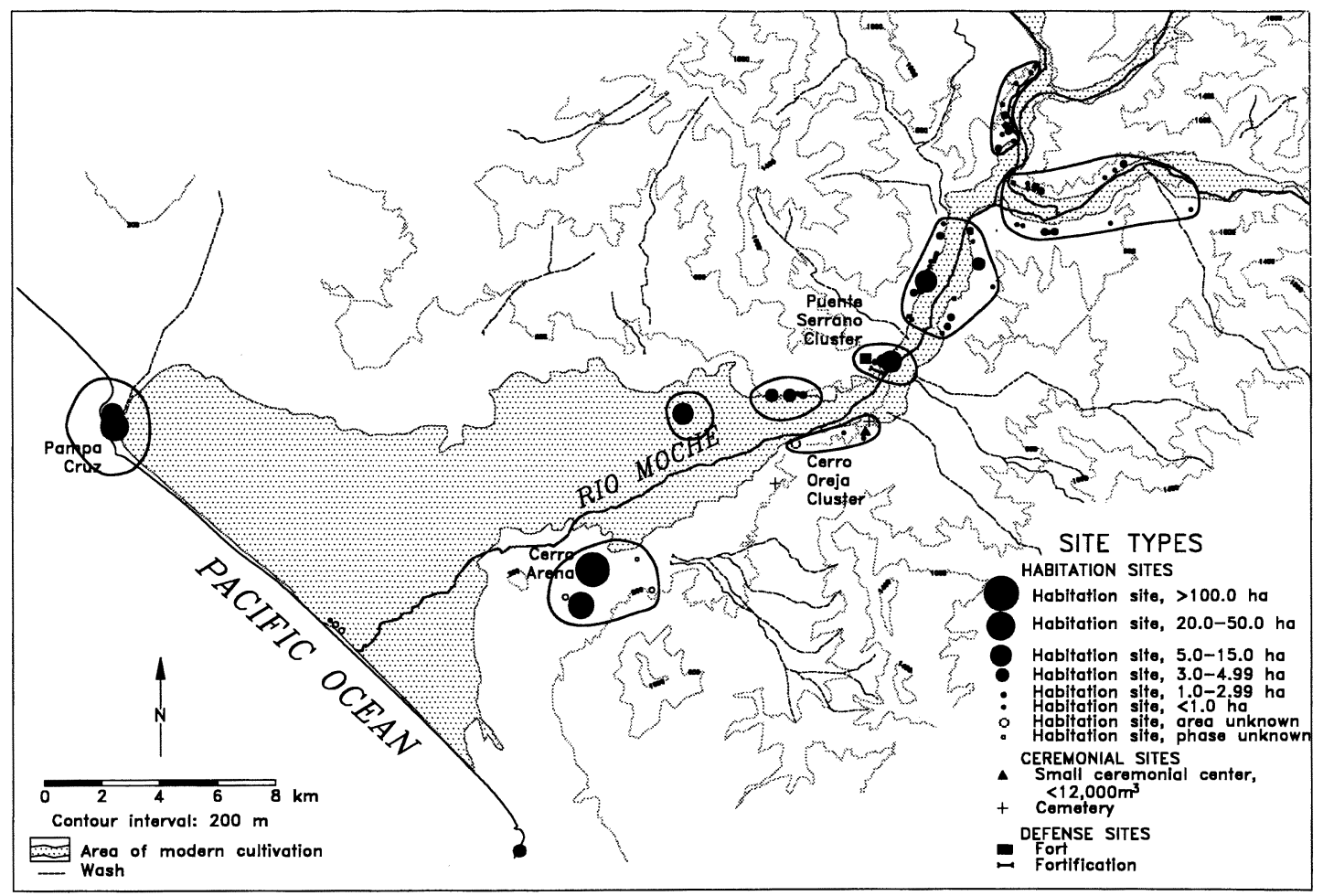

Figure 8. Location of archaeological sites dating to the Late Salinar phase, Moche Valley, Peru (200-1 B.C.).

dwellings (Brennan 1978, 1980a, 1980b). In addition, household data indicate that a small elite stratum existed at Cerro Arena (Brennan 1978, 1980a, 1980b).

Because the size of construction workforces, size of canal user groups, and frequency of water shortages increased significantly, the hydraulic model predicts that the first simple chiefdoms should have developed in this phase (Hypothesis 2). Political developments in the Salinar phase conform to some of the archaeological expectations derived from Hypothesis 2. In the Early Salinar phase, several small autonomous population clusters with internal two-tier settlement hierarchies formed in the valley. By the Late Salinar phase, nine clusters may have been joined together in a loose confederation dominated by Cerro Arena, which appears to have extracted tribute from the other clusters (Billman 1996:212). If Cerro Arena controlled other clusters, then the settlement system would have had three tiers, one more tier than predicted by the hydraulic model. Construction of public architecture dropped dramatically in the Salinar phase, although the hydraulic hypothesis predicted an increase.

\section{Gallinazo and Moche Phases}

Although political evolution in the Salinar phase loosely followed predictions derived from Hypothesis 2, political centralization in the Gallinazo and Early Moche phases increased beyond those predictions without any significant expansion in irrigation. At the start of the Gallinazo phase, the middle valley population apparently was unified into a single polity centered at Cerro Oreja (Figure 9). A separate polity may have been located at Huanchaco at Pampa Cruz. The Cerro Oreja polity had a three-tier site hierarchy with a paramount center and eight moderately sized secondary centers (Billman 1996:250-253). Approximately $67,000 \mathrm{~m}^{3}$ of ceremonial architecture were constructed in the Gallinazo and Early Moche phases compared to $15,000 \mathrm{~m}^{3}$ in the Salinar phase (Billman 1996:Tables 17.11 and 18.4), an increase of over 400 percent. The Cerro Oreja polity was much more complex and centralized than expected if only the managerial requirements of irrigation are considered.

Perhaps the most surprising result of the survey of the middle valley was the identification of 114 sites 


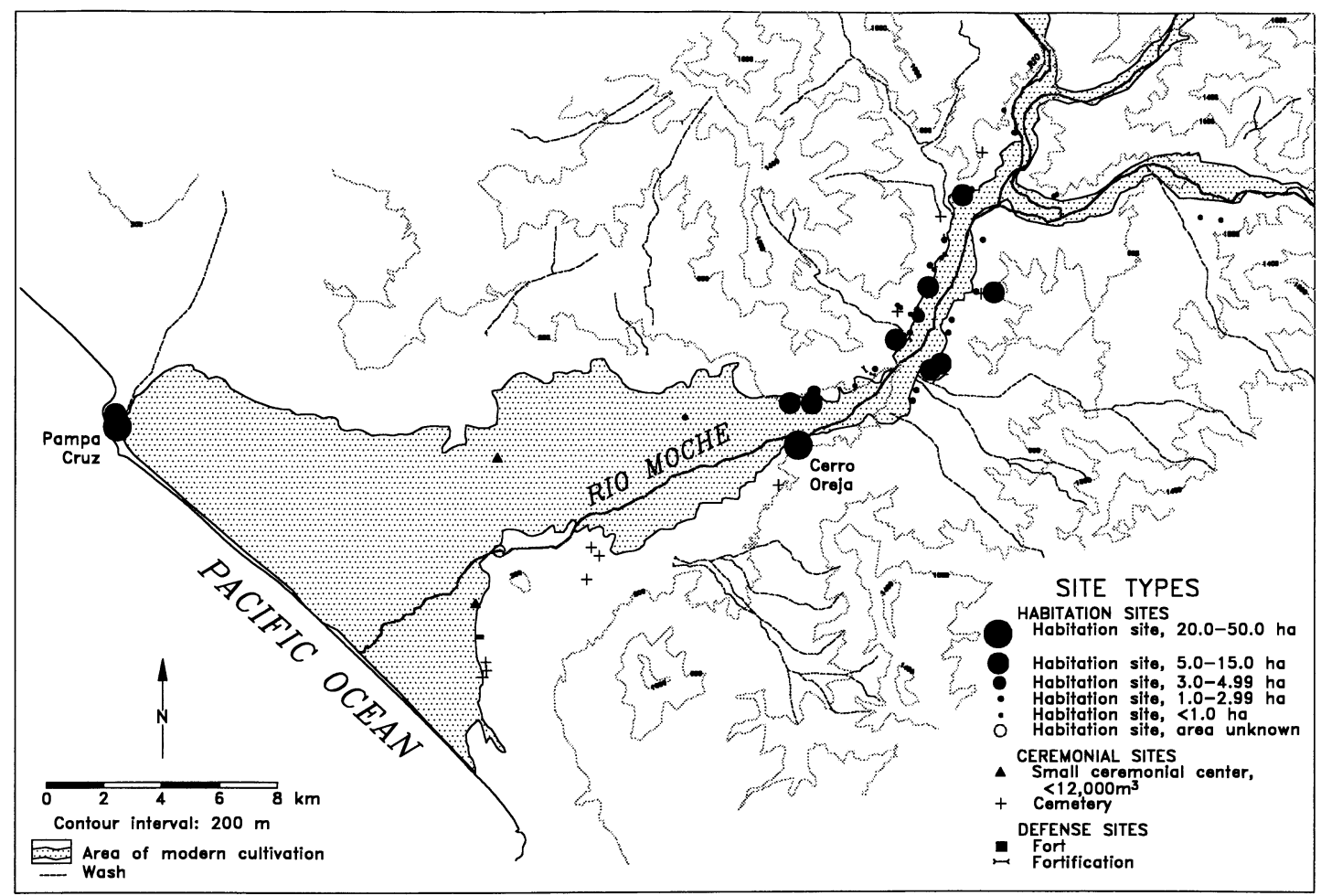

Figure 9. Location of archaeological sites dating to the Gallinazo and Early Moche phases, Moche Valley, Peru (A.D. 1-400).

that have large quantities of nonlocal Highland Early Intermediate period ceramics (HEIP) (Billman 1996:264-289, 1997). Over 90 percent of the ceramic artifacts at HEIP sites are made in highland styles rather than in coastal styles. In comparison to coastal ceramics from the same period, the ceramics from the HEIP sites are distinct in paste, vessel form, and decoration (Billman 1996:264-268). These ceramic assemblages are similar to EIP ceramics from the highland areas of the Moche, Virú, and Chicama drainages (Topic and Topic 1982). Based on excavation and survey data from the highlands (Topic and Topic 1982) and Virú Valley (Bennett 1950; Collier 1955; Ford and Willey 1949; Strong and Evans 1952), these ceramics in the Moche Valley date to the Gallinazo through Early Moche phases (Billman 1996:264-268).

HEIP sites are clustered (Figure 10) in the Sinsicap Valley (Sinsicap cluster), in the upper middle Moche Valley above the confluence of the Sinsicap River (Cruz Blanca cluster), and on the south side of the lower middle valley (Cerro León cluster) (Billman 1996:250-253, 1997), but not in the lower valley. These clusters are separated by uninhabited buffer zones of 1.1 to $3.4 \mathrm{~km}$. These gaps apparently were not a function of the distribution of arable land because it is evenly distributed along the river.

The population clusters have a two- or three-tier hierarchy of habitation sites (Billman 1996:250253). Each is dominated by a paramount site, which has large elaborate residences, suggesting the presence of an elite social stratum. The settlement hierarchy, empty spaces between clusters, and the existence of an elite stratum strongly suggest that each HEIP cluster was an autonomous centralized polity.

The large number of HEIP sites in the middle Moche Valley implies a high degree of highlandcoastal interaction just prior to the formation of the Southern Moche state. A similar pattern of intrusion of highland ceramic sites in the EIP has been documented in the Virú, Nepeña, Casma, and Lurín Valleys (Daggett 1984, 1987; Patterson et al. 1982; Pozorski and Pozorski 1987; Topic 1982:259-260; Topic and Topic 1982).

The form of highland-coastal interaction remains open to question. HEIP sites in the middle valley may represent (1) specialized production and exchange 


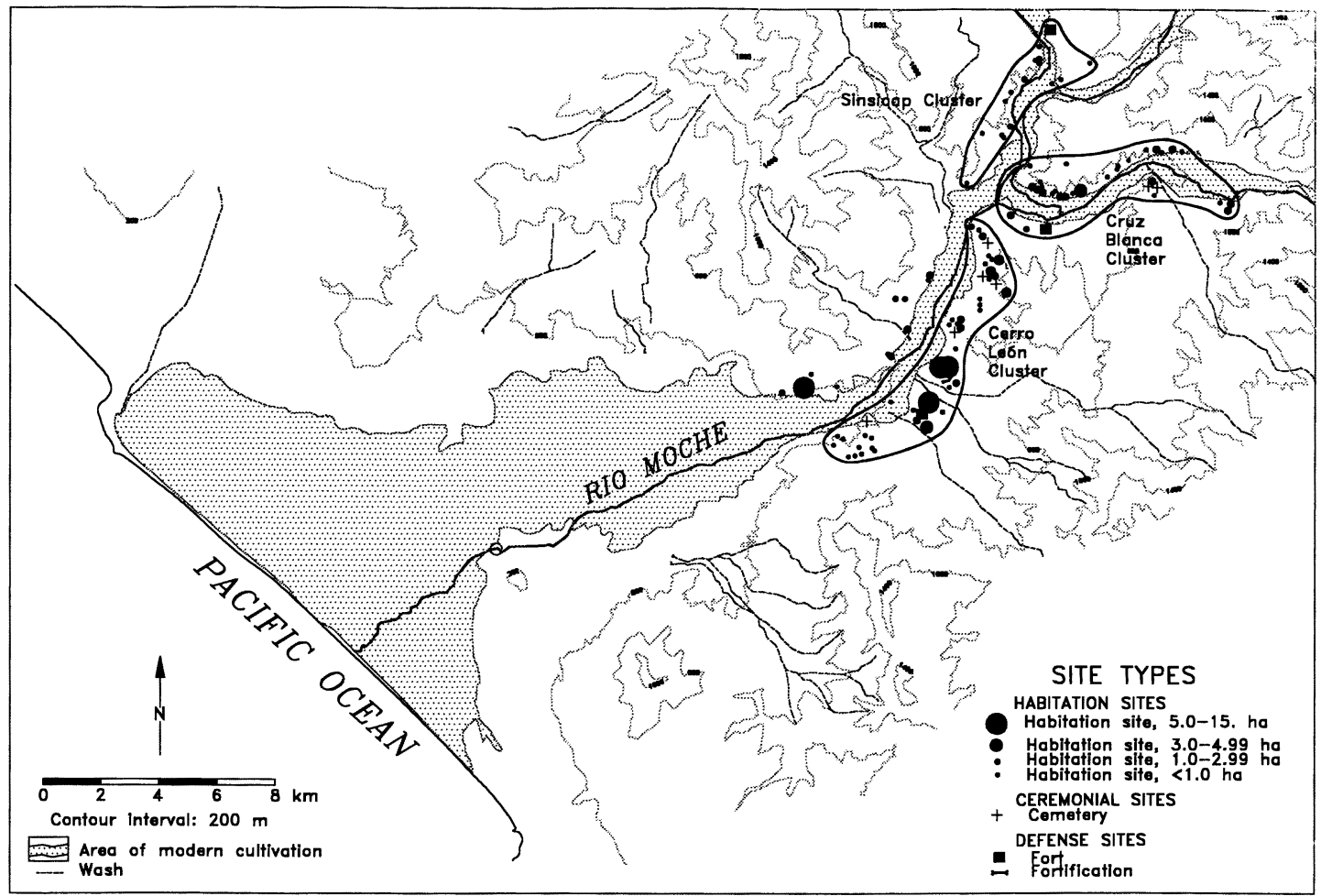

Figure 10. Location of archaeological sites with highland ceramic assemblages dating to the Gallinazo and Early Moche phases, Moche Valley, Peru (A.D. 1-400). At these sites, more than 90 percent of the ceramics are highland in style.

of goods between highland and coastal groups (Rostworowski 1977, 1978), (2) direct peaceful colonization of the middle valley by highland groups seeking access to lowland goods, i.e., vertical archipelagos (Murra 1968, 1972), or (3) violent conquest and colonization of the middle valley by highlander invaders (Billman 1996:275-276, 288-289, 1997). Each of these scenarios has profound implications for the origins of the Southern Moche state. Survey data are consistent with the third model of interaction (Billman 1996:264-289); however, excavation is needed to address the ethnic identity of HEIP residents, the nature of highland-coastal interaction, and the role that interaction played in the formation of the Southern Moche state.

Ceramic data indicate that the HEIP sites were abandoned before the start of the Middle Moche phase (Figure 11) (Billman 1996:264-268) when the Southern Moche state emerged, unifying all of the middle and lower valley. The capital of the valley shifted from Cerro Oreja to the site of Moche. Once control of the valley was achieved, the Southern Moche state expanded south and north, inte- grating adjacent valleys into the Moche political and economic system (Billman 1996:329-333, Conrad 1978; Topic 1982:270-273; Willey 1953:397; Wilson 1988:222-224, 1995).

Leaders of the Southern Moche state directed the construction of large public monuments in the Moche and neighboring valleys at which they conducted elaborate public rituals for large audiences (Billman 1996:317-319; Uceda 1997). One of the largest prehistoric monuments in the New World-Huaca del Sol-was constructed at Moche (Hastings and Moseley 1975; Moseley 1975b). The total volume of Middle Moche phase ceremonial architecture dwarfs construction in the preceding Gallinazo and Early Moche phases. The volume of ceremonial architecture constructed in the Moche Valley during the Middle Moche phase was approximately 1,291,000 $\mathrm{m}^{3}$, nearly 20 times that of the Gallinazo and Early Moche phases (Billman 1996:317-318).

Leaders also directed the construction of large reclamation projects in Moche, Chicama, and Santa Valleys (see for example Wilson 1988:198-223). Craft goods, especially fineware ceramics, were produced 


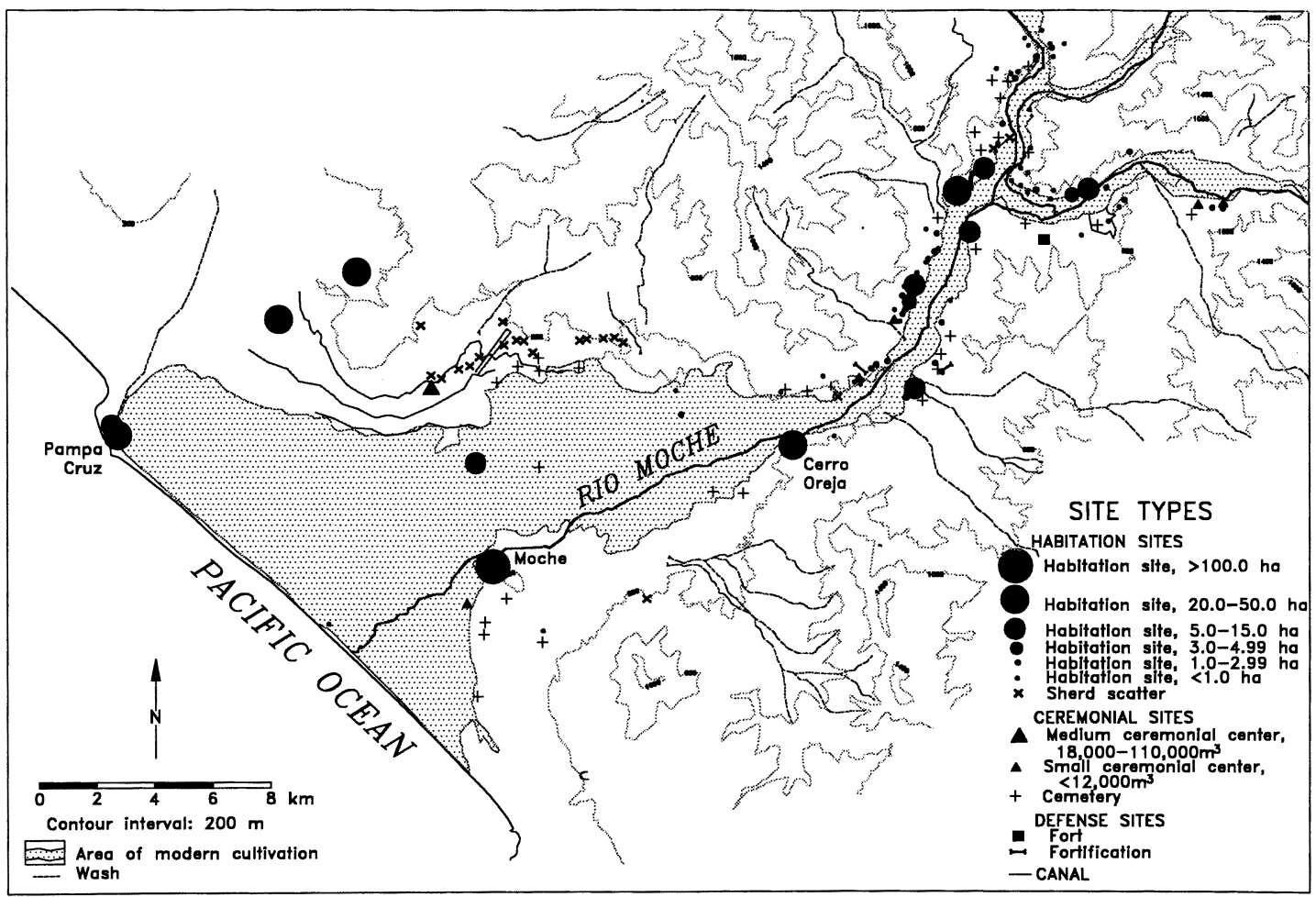

Figure 11. Location of archaeological sites dating to the Middle Moche phase, Moche Valley, Peru (A.D. 400-800). The location of 27 Middle Moche phase sites recorded by the Chan Chan-Moche Project on Pampa Esperanza could not be determined.

in amounts never before seen on the coast (Alva and Donnan 1993; Larco 2001; Russell et al. 1994, 1998; Shimada 1994:191-215; Uceda and Armas 1997, 1998). Leaders amassed large quantities of these wealth goods for use in their households and burials (Alva and Donnan 1993; Castillo and Donnan 1994; Uceda 1997). Leaders also mobilized laborers to construct large well-made, elaborately finished residences (Topic 1977, 1982; Tello 1998; Van Gijseghem 2001).

The hydraulic model predicts the first valley-wide polity would have emerged in the Middle Moche phase (Hypothesis 3). However, the Southern Moche state is significantly more complex than predicted. Management-oriented models predict that this type of regional polity should not have occurred until the LIP when the far-north side of the valley was reclaimed and La Cumbre Intervalley canal constructed (Hypothesis 4). Although Moche leaders apparently did organize the construction of large canals in the Moche Valley, construction appears to have occurred after leaders had consolidated their control over the entire valley and created a centralized polity at the site of Moche.

\section{Conclusions}

In the Guañape phase, during the first cycle of political centralization in the Moche Valley, the managerial requirements of canal construction do not appear to have been a major catalyst of political change. Canals were short and relatively easy to construct; canal user groups were small and self-sufficient; and water shortages were probably rare. Canals could have been constructed, used, and managed at the village or community level. Warfare also apparently was not a factor in Guañape phase social or political life. If armed conflict occurred, it was not of sufficient severity to become evident in the pattern of settlement (Billman 1996:181-183, 1997, 1999). Population did not aggregate or shift to defensive locations, and no fortifications were constructed. If we are to understand what factors were responsible for the formation of Guañape phase polities, we must look elsewhere.

The answer may be found in the opportunities for development of social stratification and political control created by changes in the subsistence economy 
at the beginning of the Guañape phase. The productive system during the Late Preceramic period provided few if any opportunities for economic control by leaders. Simple technologies provided easy access to near-shore resources for any fit individual. Agricultural land was still abundant, and floodplain agriculture required slash-and-burn or simple irrigation techniques. The absence of intensive armed conflict provided few opportunities for leaders to exercise coercive power. In order to maintain leader-follower relationships, leaders probably had to rely on personal charisma, ideology, and redistribution of surpluses produced by their own households and the households of their followers.

The rich marine environment had the potential to yield considerable surplus in this period. Several features at Alto Salaverry may have been used for the storage of large quantities of dried fish (Billman 1996:104-113, 1999). In the hands of aspiring leaders, surpluses of fish and other marine goods could have been used to enhance their status and influence. Surpluses could have been used to finance political activities-such as dances, feasts, and other ceremonies - that created obligatory relationships between leader-donors and follower-recipients. In this scenario, leaders did not control any part of the means of production, but they were capable of generating surpluses that enhanced their status and helped them to form coalitions of followers.

With the shift to irrigation in the Guañape phase, emerging leaders had new opportunities for political control and the accumulation of goods. Although the initial cost of constructing irrigation canals was higher than the costs of fishing and floodplain agriculture, once in production, irrigation systems dramatically increased yields. Consequently, by organizing and financing the construction of irrigation systems, leaders potentially could have then extracted surpluses from canal users to fund further political activity, such as monument construction, and to further elevate the socioeconomic status of their own households. Irrigation systems also created opportunities for leaders to control land and the flow of water. The political consequence was that in the Early Guañape phase political leaders not only could have controlled increased agricultural production, but also the distribution of land and water. With these newfound sources of economic power, leaders were able to finance the creation of centralized, hierarchical political organizations.
In short, although the managerial requirements of irrigation were minimal in the Guañape phase, opportunities for political control and finance were great. Therefore, political models may be more effective in explaining the centralized polities in the Guañape phase than the managerial models proposed by Wittfogel, Steward, and others. Construction of three moderate-sized lower-valley canals in Middle and Late Guañape may have been particularly important in increasing the economic power of leaders. With the investment of relatively small quantities of labor-each of those canals could have been constructed by less than 60 people working for one season-leaders could have reclaimed perhaps 1,300 ha of land, which could have supported 1,800-2,600 people. Leaders may have been in a position to grant use-rights to commoners in exchange for annual payments in labor or a percentage of the harvest. This sort of patron-client relationship apparently existed between lords and commoner farmers on the north coast before Spanish conquest and was the foundation of the political economy of the Chimu state (Netherly 1984). Such relationships are also a relatively common form of political control and finance in a wide range of historic chiefdoms and states (see Earle 1997:67-89; Sidky 1996).

Labor service payments perhaps were used to construct the mounds at Caballo Muerto. As noted previously, during the Guañape phase nearly six times more earth was excavated for mound construction than in the construction of all of the Guañape phase canals. By investing labor service in the ideological infrastructure, leaders would have been able to greatly expand their ideological power base. Control of large monuments would have enabled leaders to materialize and disseminate an ideological message that both legitimized their elevated political status and the annual payment of goods or services by farming households. In essence, their control of ceremonial centers and the public and private rituals conducted at them allowed leaders to control the means of ideological production. Consequently, the creation of centralized polities by leaders in the Guañape phase primarily may have been based on two mutually reinforcing sources of power: control of irrigation systems and control of ceremonial centers.

The pattern of political development in the EIP differed significantly from that of the Guañape phase. Warfare and highland-coastal interaction appear to 
have been important factors influencing the formation of polities in that period (Billman 1996, 1999). Guañape phase polities and their associated ideology apparently were destroyed by armed conflict by the start of the Salinar phase, and a new political order was created. In the Salinar phase, the population of the valley aggregated into several clusters for selfdefense. As violent conflict increased in the subsequent Gallinazo and Early Moche phases, autonomous population clusters coalesced into a valley-wide polity centered at Cerro Oreja. Rising levels of violent conflict in the EIP may have created opportunities for leaders to organize and direct defense, plan offensive actions, and negotiate alliances. Control of military and diplomatic activities may have constituted a new power base in this period. Escalation of conflict was paralleled by increased highland-coastal interaction, which also may have been violent in nature. Highland-coastal interaction peaked just prior to the formation of the Southern Moche state with the development of three HEIP site clusters in the middle valley.

Once they consolidated their military control of the Moche Valley and expelled or assimilated highlanders in the middle valley, leaders appear to have directed a major expansion of the irrigation system. More than 7,000 ha were reclaimed by the construction of three canals on the north side of the valley, supporting between 12,700 and 18,200 people. Annual payments of goods or services by tenant farmers on newly reclaimed land would have vastly increased the economic power base of Moche leaders, as dramatically illustrated by the construction $1,200,000 \mathrm{~m}^{3}$ of monumental architecture in the Moche Valley during the Middle Moche phase. Annual tribute payments by thousands of households on newly reclaimed land on the north side of the valley provides a key to solving the puzzle of how Moche leaders were able to consistently mobilize vast quantities of labor, whereas previous political leaders could not. Leaders had never before created such a large group of tribute-paying farmers.

Agricultural tribute apparently also was used to support craft specialists, who created large quantities of wealth goods (Attarian 1996; Russell et al. 1994, 1998; Uceda and Armas 1997, 1998). Leaders may have used the distribution of those wealth goods to disseminate state ideology and maintain political alliances, creating an effective system of wealth finance and political propaganda from a system of staple finance. After consolidation of control of the Moche Valley, they led the conquest of adjacent valleys. Following the same strategy employed in the Moche Valley, Moche leaders undertook major reclamation projects in some of those valleys and constructed provincial centers with large monuments and craft workshops.

In sum, evaluation of the hydraulic hypothesis indicates that the managerial requirements of production (specifically canal construction, integration of households, and disputes resolution) were relatively unimportant in the formation of centralized polities in the Moche Valley. Currently available data suggest that the expansion of irrigation in the Guañape phase may have allowed leaders to gain control of crucial aspects of the means of production. Control of land, labor, and water permitted them to create the first centralized valley-wide polity. Centralized institutions of rule were not required to construct and manage Guañape phase irrigation canals; neither warfare nor the managerial requirements of irrigation were important factors. The managerial requirements of irrigation also were probably relatively unimportant in the formation of the Southern Moche state. Warfare, highland-coastal interaction, and political control of irrigation systems created opportunities for leaders to form a highly centralized, territorially expansive state.

Acknowledgments. Funding for fieldwork and analysis was provided by an NSF Dissertation Improvement Grant, Fulbright Fellowship, Sigma Xi Grant-in-Aid of Research, UCSB Humanities-Social Science Grant, Dumbarton Oaks Pre-Columbian Fellowship, and UNC Research Council Publication grant. I thank the Instituto Nacional de Cultura for permission to conduct research in the Moche Valley and for the support of Anna Maria Hoyle, Santiago Uceda, Jesus Briceño, and César Gálaz at the INC office in Trujillo. I am deeply indebted to Carlos Ramirez, Jorge Sechun, Alfredo Melly, Lucia Medina, Flor Diez, and Theresa Vasallo for their hard work in field and lab. My thanks also go to Michael Moseley and Carol Mackey, who provided access to the Chan ChanMoche Valley Project's site files. Ellen O'Brian, Colleen Winchell, Chris Rodning, and Jennifer Ringberg drafted the illustrations. The Spanish abstract was translated by Julio Rucabado. I would like to thank Gary Feinman, Jonathan Haas, Charles Hastings, Joyce Marcus, Mintcy Maxham, Michael Moseley, Chris Rodning, Katharina Schreiber, Tiffiny Tung, Henry Wright, and seven anonymous reviewers for their comments on the paper. I greatly appreciate the patience and guidance of Gary Feinman, Kathy Schreiber, and Suzanne Fish during their editorship of Latin American Antiquity. 


\section{References Cited}

Adams, Robert McC.

1966 The Evolution of Urban Society: Early Mesopotamia and Pre-Hispanic Mexico. Aldine, Chicago.

1968 Early Civilization, Subsistence, and Environment. In Man in Adaptation: The Biological Background, edited by Y. Cohen, pp. 363-377. Aldine, Chicago.

Alva, Walter, and Christopher B. Donnan

1993 Royal Tombs of Sipán. Fowler Museum of Culture History, University of California, Los Angeles.

Attarian, Christopher J.

1996 Plant Foods and Ceramic Production: A Case Study of Mochica Ceramic Production Specialists in the Chicama Valley, Peru. Unpublished M.A. thesis, Department of Anthropology, University of California, Los Angeles.

Bawden, Garth

1996 The Moche. Blackwell Publishers, Cambridge, Massachusetts.

Bennett, Wendell C.

1950 The Gallinazo Group Virú Valley, Peru. Yale University Publications in Anthropology, No 43. Yale University Press, New Haven, Connecticut.

Billman, Brian R.

1989 Land, Water, and Architecture: The Economic and Political Organization of an Early Andean State. Unpublished M.A. paper, Department of Anthropology, University of California, Santa Barbara.

1996 The Evolution of Prehistoric Political Organizations in the Moche Valley, Peru. Unpublished Ph.D. dissertation, Department of Anthropology, University of California, Santa Barbara.

1997 Population Pressure and the Origins of Warfare in the Moche Valley, Peru. In Integrating Archaeological Demography: Multidisciplinary Approaches to Prehistoric Populations, edited by R. R. Paine, pp. 285-310. Occasional Paper No. 24, Center for Archaeological Investigations, University of Southern Illinois at Carbondale.

1999 Reconstructing Prehistoric Political Economies and Cycles of Political Power in the Moche Valley, Peru. In Settlement Pattern Studies in the Americas: Fifty Years Since Virú, edited by B. R. Billman and G. M. Feinman, pp. 131-159. Smithsonian Institution Press, Washington, DC.

Binford, Lewis

1983 In Pursuit of the Past. Thames and Hudson, New York.

Blanton, Richard E., Gary M. Feinman, Stephen A. Kowalewsky, and Peter N. Peregrine

1996 A Dual-Process Theory of the Evolution of Mesoamerican Civilization. Current Anthropology 26:1-14.

Bourget, Steve

1997 Las excavaciones en la Plaza 3A de la Huaca de Luna. In Investigaciones en la Huaca de la Luna 1995, edited by S. Uceda, E. Mujica, and R. Morales, pp. 51-60. Facultad de Ciencias Sociales, Universidad Nacional de la LibertadTrujillo, Peru.

2001 Children and Ancestors: Ritual Practices at the Moche Site of Huaca de la Luna, North Coast of Peru. In Ritual Sacrifice in Ancient Peru, edited by E. P. Benson and A. G. Cook, pp. 93-119. University of Texas Press, Austin.

Brennan, Curtiss T.

1978 Investigations at Cerro Arena, Peru: Incipient Urbanism on the North Coast of Peru. Unpublished Ph.D. dissertation, Department of Anthropology, University of Arizona, Tucson.

1980a Cerro Arena: Early Cultural Complexity and Nucleation in North Coastal Peru. Journal of Field Archaeology $7: 1-22$. 1980b Cerro Arena: Rise of the Andean Elite. Archaeology 33:6-13.

Brumfiel, Elizabeth M.

1992 Distinguished Lecture in Archaeology: Breaking and Entering the Ecosystem: Gender, Class, and Faction Steal the Show. American Anthropologist 94:551-567.

Brumfiel, Elizabeth M., and Timothy K. Earle

1987 Specialization, Exchange, and Complex Societies: An Introduction. In Specialization, Exchange, and Complex Societies, edited by E. M. Brumfiel and T. K. Earle, pp. 1-9. Cambridge University Press, Cambridge.

Butzer, Karl W.

1976 Early Hydraulic Civilization in Egypt: A Study in Cultural Ecology. University of Chicago Press, Chicago.

Castillo, Luis Jaime, and Christopher B. Donnan

1994 La ocupación Moche de San José Moro, Jequetepeque. In Moche: propuestas y perspectivas, edited by S. Uceda and E. Mujica, pp. 93-146. Actas de Primer Coloquio sobre la Cultura Moche. Travaux de l'Institut Français d'Etudes Andines 79. IFEA, FOMCIENCIAS, and UNT, Lima.

1995 Los Mochicas del norte y los Mochicas del sur. In Vicús, edited by K. Makowski, C. B. Donnan, I. Amaro Bullon, L. J. Castillo, M. Diez Canseco, O. Eléspuru Revoredo, and J. A. Murro Mena, pp. 143-176. Banco de Crédito del Perú, Lima.

Chapdelaine, Claude

1998 Excavaciones en la zona urbana de Moche durante 1996. In Investigaciones en la Huaca de la Luna 1996, edited by S. Uceda, E. Mujica, and R. Morales, pp. 85-116. Facultad de Ciencias Sociales, Universidad Nacional de la LibertadTrujillo, Peru.

Chapdelaine, Claude, Victor Pimentel, and Hélène Bernier

2001 A Glimpse of Moche Phase III Occupation at the Huacas of Moche Site, Northern Peru. Antiquity 75:361-372.

Cohen, Mark N.

1978 Population Pressure and the Origins of Agriculture: An Archaeological Example from the Coast of Peru. In Advances in Andean Archaeology, edited by D. L. Browman, pp. 91-132. Mouton Publishers, The Hague.

1981 The Ecological Basis of New World State Formation: General and Local Model Building. In The Transition to Statehood in the New World, edited by G. D. Jones and R. R. Kautz, pp. 105-122. Cambridge University Press, Cambridge.

Collier, Donald

1955 Cultural Chronology and Change as Reflected in the Ceramics of the Virú Valley, Peru. Fieldiana: Anthropology Vol. 43. Chicago Natural History Museum, Chicago.

Conrad, Goeffrey W.

1978 Models of Compromise in Settlement Pattern Studies: An Example from Coastal Peru. World Archaeology 9(3):280-298.

Daggett, Richard

1984 The Early Horizon Occupation of the Nepeña Valley, Peru. Unpublished Ph.D. dissertation, Department of Anthropology, University of Massachusetts, Amherst.

1987 Toward the Development of the State on the North Central Coast of Peru. In The Origins and Development of the Andean State, edited by J. Haas, S. Pozorski, and T. Pozorski, pp. 70-82. Cambridge University Press, Cambridge.

D'Altroy, Terence N., and Timothy K. Earle

1985 Staple Finance, Wealth Finance, and Storage in the Inka Political Economy. Current Anthropology 26:187-206.

DeMarrais, Elizabeth, Luis Jaime Castillo, and Timothy K. Earle 1996 Ideology, Materialization, and Power Strategies. Current Anthropology 37:15-31. 
Donnan, Christopher B.

1973 Moche Occupation of the Santa Valley, Peru. University of California Publications in Anthropology, Vol. 8. University of California, Berkeley.

1976 Moche Art and Iconography. UCLA Latin American Center Publications, University of California, Los Angeles.

Earle, Timothy K.

1976 Nearest Neighbor Analysis of Two Formative Settlement Systems. In The Early Mesoamerican Village, edited by K. V. Flannery, pp. 196-223. Academic Press, New York.

1978 The Economic and Social Organization of a Complex Chiefdom: The Halelea District, Kaua'i, Hawaii. Museum of Anthropology Anthropological Papers No. 63. University of Michigan, Ann Arbor.

1987 Specialization and the Production of Wealth: Hawaiian Chiefdoms and the Inka Empire. In Specialization, Exchange, and Complex Societies, edited by E. M. Brumfiel and T. K. Earle, pp. 64-75. Cambridge University Press, Cambridge.

1997 How Chiefs Come to Power: The Political Economy in Prehistory. Stanford University Press, Stanford.

2001 Economic Support of Chaco Society. American Antiquity 66:26-35.

Emerson, Robert M.

1990 Charismatic Kingship: A Study of State-Formation and Authority in Baltistan. In Pakistan: The Social Sciences' Perspective, edited by A. S. Ahmed, pp. 100-145. Oxford Press, Karachi.

Erasmus, Charles J.

1965 Monument Construction: Some Field Experiments. Southwest Journal of Anthropology 21:277-301.

Farrington, Ian

1974 Irrigation and Settlement Pattern: Preliminary Research Results from the North Coast of Peru. In Irrigation's Impact on Society, edited by T. E. Downing and M. Gibson, pp. 83-94. Anthropological Papers of the University of Arizona No. 25. University of Arizona Press, Tucson.

1985 Operational Strategies, Expansion, and Intensification within the Prehistoric Irrigation System of the Moche Valley, Peru. In Prehistoric Intensive Agriculture in the Tropics, edited by I. S. Farrington, pp. 621-652. BAR International Series 232, Oxford, England.

Feinman, Gary M.

1995 The Emergence of Inequality: A Focus on Strategies and Process. In Foundations of Social Inequality, edited by T. D. Price and G. M. Feinman, pp. 255-280. Plenum Publishing Corporation, New York.

Feinman, Gary M., and Jill Neitzel

1984 Too Many Types: An Overview of Sedentary Prestate Societies in the Americas. In Advances in Archaeological Method and Theory, Volume 7, edited by M. B. Schiffer, pp. 39-102. Academic Press, New York.

Flannery, Kent V.

1998 The Ground Plans of Archaic States. In Archaic States, edited by Gary M. Feinman and J. Marcus, pp. 15-58. School of American Research Press, Santa Fe.

Ford, James A., and Gordon R. Willey

1949 Surface Survey of the Virú Valley, Peru. Anthropological Papers of the American Museum of Natural History Vol 43: Part 1. American Museum of Natural History, New York.

Fried, Morton $\mathrm{H}$.

1967 The Evolution of Political Society. Random House, New York.

Gillin, John P.

1945 Moche: A Coastal Peruvian Community. Institute of Social Anthropology Publications No. 3. Smithsonian Institution, Washington, DC
Gray, Robert F.

1963 The Sonjo of Tanganyika: An Anthropological Study of an Irrigation-Based Society. Oxford University Press, London.

Haas, Jonathan

1981 Class Conflict and the State in the New World. In The Transition to Statehood in the New World, edited by G. D. Jones and R. R. Kautz, pp. 80-102. Cambridge University Press, Cambridge.

1982 The Evolution of the Prehistoric State. Columbia University Press, New York.

1985 Excavations on Huaca Grande: An Initial View of the Elite of Pampa Grande, Peru. Journal of Field Archaeology 12:391-409.

1987 The Exercise of Power in Early Andean State Development. In The Development and Origins of the Andean State, edited by J. Haas, S. Pozorski, and T. Pozorski, pp. 31-35. Cambridge University Press, Cambridge.

Harris, Marvin

1977 Cannibals and Kings: The Origins of Culture. Vintage, New York.

Hassan, Fekri

1981 Demographic Archaeology. Academic Press, New York.

Hastings, Charles M., and Michael E. Moseley

1975 The Adobes of Huaca del Sol and Huaca de la Luna. American Antiquity 40:196-203.

Hatch, John K.

1976 The Corn Farmers of Motupe: A Study of Traditional Farming Practices in Northern Coastal Peru. Land Tenure Center Monographs No. 1. University of Wisconsin, Madison.

Howard, Jerry B., and Gary Huckleberry

1991 The Operation and Evolution of an Irrigation System: The East Papago Canal Study. Soil Systems Publications in Archaeology No. 18. Soil Systems, Inc., Phoenix.

Hunt Eva, and Robert C. Hunt

1974 Irrigation, Conflict, and Politics: A Mexican Case. In Irrigation's Impact on Society, edited by T. E. Downing and M. Gibson, pp. 129-158. Anthropological Papers of the University of Arizona, No. 25. University of Arizona, Tucson.

Isbell, William H., and Katharina Schreiber

1978 Was Huari a State? American Antiquity 43:372-389.

Johnson, Allen W., and Timothy K. Earle

1987 The Evolution of Human Society: From Foraging Group to Agrarian State. Stanford University Press, Stanford.

Johnson, Gregory A.

1973 Local Exchange and Early State Development in Southwestern Iran. Museum of Anthropology Anthropological Papers No. 51. University of Michigan, Ann Arbor.

Lanning, Edward

1967 Peru Before the Incas. Prentice-Hall, Englewoods Cliffs, New Jersey.

Larco, Rafael

2001 Los Mochicas: Tomos Iy II. Museo Arqueológico Rafael Larco Herrera, Lima.

Leach, Edmund R.

1959 Hydraulic Society in Ceylon. Past and Present 15:2-26.

Lees, Susan H.

1974 The State's Use of Irrigation in Changing Peasant Society. In Irrigation's Impact on Society, edited by T. E. Downing and M. Gibson, pp. 123-128. Anthropological Papers of the University of Arizona No. 25. University of Arizona, Tucson.

Massey, Sarah A.

1986 Sociopolitical Change in the Upper Ica Valley, 400 B.C. to A.D. 400. Unpublished Ph.D. dissertation, Department of Anthropology, University of California, Los Angeles.

Mitchell, William P.

1973 The Hydraulic Hypothesis Revisited: A Reappraisal. 
Current Anthropology 14:532-534.

1976 Irrigation and Community in the Central Peruvian Highlands. American Anthropologist 78:25-44.

Moore, Jerry

1996a The Archaeology of Plazas and the Proxemics of Ritual: Three Andean Traditions. American Anthropologist 98:789-802.

1996b Architecture and Power in the Prehispanic Andes. Cambridge University Press, Cambridge.

Moseley, Michael E.

1974 Organizational Preadaptation to Irrigation: The Evolution of Early Water-Management Systems in Coastal Peru. In Irrigation's Impact on Society, edited by T. E. Downing and M. Gibson, pp. 77-82. Anthropological Papers of the University of Arizona No. 25. University of Arizona, Tucson.

1975a The Maritime Foundations of Andean Civilizations. Cummings Publishing, Menlo Park, California.

1975b Prehistoric Principles of Labor Organization in the Moche Valley, Peru. American Antiquity 40:191-196.

1992 The Inkas and Their Ancestors. Thames and Hudson, London.

Moseley, Michael E., and Eric E. Deeds

1982 The Land in Front of Chan Chan: Agrarian Expansion, Reform, and Collapse in the Moche Valley. In Chan Chan: Andean Desert City, edited by M. E. Moseley and K. C. Day, pp. 25-54. University of New Mexico Press, Albuquerque.

Murra, John V.

1968 An Aymara Kingdom in 1567. Ethnohistory $15: 115-151$.

1972 El "control vertical" de un máximo de pisos ecológicos en la economía de las sociedades andinas. In Visita de la Provincia de León de Huánuco en 1562. Documentos por la Historia y Etnología de Huánuco y la Selva Central 1:427-476. Universidad Nacional Hermilio Valdizán, Huánuco.

Netherly, Patricia J.

1984 The Management of Late Andean Irrigation Systems on the North Coast of Peru. American Antiquity 49:227-254.

Netting, Robert M.

1974 The System Nobody Knows: Village Irrigation in the Swiss Alps. In Irrigation's Impact on Society, edited by T. E. Downing and M. Gibson, pp. 67-76. Anthropological Papers of the University of Arizona No. 25. University of Arizona, Tucson.

ONERN (Oficina Nacional de Evaluación de Recursos Naturales)

1973 Inventario, evaluación, y uso racional de los recursos naturales de la costa: cuenca del Rio Moche, Vol. I and II. Oficina Nacional de Evaluación de Recursos Naturales, Lima.

Ortloff, Charles R., Robert A. Feldman, and Michael E. Moseley 1985 Hydraulic Engineering and Historical Aspects of the Pre-Columbian Intravalley Canal Systems of the Moche Valley, Peru. Journal of Field Archaeology 12:77-98.

Patterson, Thomas C., John P. McCarthy, and Robert A. Dunn 1982 Polities in the Lurín Valley during the Early Intermediate Period. Ñawpa Pacha 20:61-82.

Peebles, Christopher S.

1978 Determinants of Site Size and Location in the Moundville Phase. In Mississippian Settlement Patterns, edited by B. D. Smith, pp. 369-417. Academic Press, New York.

Pozorski, Shelia, and Thomas Pozorski

1979a Alto Salaverry: A Peruvian Coastal Cotton Preceramic Site. Annals of the Carnegie Museum 49:337-375. Carnegie Museum of Natural History, Pittsburgh. 1979b An Early Subsistence Exchange System in the Moche Valley, Peru. Journal of Field Archaeology 6:413-432.

1987 Early Settlement and Subsistence in the Casma Valley Peru. University of Iowa Press, Iowa City.

Pozorski, Thomas

1976 Caballo Muerto: A Complex of Early Ceramic Sites in the Moche Valley, Peru. Unpublished Ph.D. dissertation, Department of Anthropology, University of Texas, Austin.

1980 The Early Horizon Site of Huaca de los Reyes: Societal Implications. American Antiquity 45:100-110.

1982 Early Social Stratification and Subsistence Systems: The Caballo Muerto Complex. In Chan Chan: Andean Desert City, edited by M. E. Moseley and K. C. Day, pp. 225-253. University of New Mexico Press, Albuquerque.

1983 The Caballo Muerto Complex and Its Place in the Andean Chronological Sequence. Annals of the Carnegie Museum 53:1-39. Carnegie Museum of Natural History, Pittsburgh.

1987 Changing Priorities in the Chimu State: The Role of Irrigation Agriculture. In The Origins and Development of the Andean State, edited by J. Haas, S. Pozorski, and T. Pozorski, pp. 111-120. Cambridge University Press, Cambridge.

Pozorski, Thomas, and Shelia Pozorski

1982 Reassessing the Chicama-Moche Intervalley Canal: Comments on "Hydraulic Engineering Aspects of the Chimu Chicama-Moche Intervalley Canal." American Antiquity 47:851-868.

Renfrew, Colin

1974 Beyond a Subsistence Economy: The Evolution of Social Organization in Prehistoric Europe. In Reconstructing Complex Societies: An Archaeological Colloquium, edited by C. B. Moore, pp. 69-95. Bulletin of the American School of Oriental Research 20.

Rostworowski de Diez Canseco, María

1977 Etniay sociedad: costa peruana prehispánica. Instituto de Estudios Peruanos, Lima.

1978 Señoríos indígenas de Lima y Canta. Instituto de Estudios Peruanos, Lima.

Rowe, John

1963 Urban Settlements in Ancient Peru. Nawpa Pacha $1: 1-27$.

Russell, Glen S., Banks L. Leonard, and Jésus Briceño

1994 Cerro Mayal: nuevos datos sobre producción de cerámica Moche en el Valle Chicama. In Moche: propuestas y perspectivas, edited by S. Uceda and E. Mujica, pp. 181-206. Actas de Primer Coloquio sobre la Cultura Moche. Travaux de l'Institut Français d'Études Andines 79. IFEA, FOMCIENCIAS, and UNT, Lima.

1998 The Cerro Mayal Workshop: Addressing Issues of Craft Specialization in Moche Society. In Andean Ceramics: Technology, Organization, and Approaches, edited by I. Shimada, pp. 63-91. MASCA Research Papers in Science and Archaeology, Supplement to Volume 15. University of Pennsylvania Museum of Anthropology and Archaeology, Philadelphia.

Sanders, William T., and Jeffrey Marino

1970 New World Prehistory: Archaeology of the American Indian. Prentice-Hall, Englewood Cliffs, New Jersey.

Sanders, William T., Jeffrey Parsons, and Robert S. Santley

1979 The Basin of Mexico. Academic Press, New York.

Sanders, William T., and Barbara J. Price

1968 Mesoamerica: The Evolution of Civilization. Random House, New York.

Schaedel, Richard P.

1985 The Transition from Chiefdom to State on the Northern Peru. In The Evolution of Sociopolitical Organization, edited 
by H. J. M. Claessen, P. van der Velde, and E. Smith, pp. 156-169. Bergin and Garvey, South Hadley, Massachusetts. Service, Elman R.

1962 Primitive Social Organization: An Evolutionary Perspective. Random House, New York.

1975 The Origins of the State and Civilization: The Process of Cultural Evolution. Norton Press, New York.

1985 A Century of Controversy: Ethnological Issues from 1860 to 1960. Academic Press, New York.

Shimada, Izumi

1987 Horizontal and Vertical Dimensions of Prehistoric States in North Peru. In The Origins and Development of the Andean State, edited by J. Haas, S. Pozorski, and T. Pozorski, pp. 130-144. Cambridge University Press, Cambridge.

1994 Pampa Grande and the Mochica Culture. University of Texas Press, Austin.

Sidky, Homayun

1996 Irrigation and State Formation in Hunza: The Anthropology of a Hydraulic Kingdom. University Press of America, Inc., New York.

Spooner, Brian

1974 Irrigation and Society: The Iranian Plateau. In Irrigation's Impact on Society, edited by T. E. Downing and M. Gibson, pp. 43-58. Anthropological Papers of the University of Arizona No. 25. University of Arizona, Tucson.

Stanish, Charles

1994 The Hydraulic Hypothesis Revisited: Lake Titicaca Basin Raised Fields in Theoretical Perspective. Latin American Antiquity 5:312-332.

Steponaitis, Vincas P.

1978 Location Theory and Complex Chiefdoms: A Mississippian Example. In Mississippian Settlement Patterns, edited by B. D. Smith, pp. 417-453. Academic Press, New York.

1981 Settlement Hierarchies and Political Complexity in NonMarket Societies: The Formative Period of the Valley of Mexico. American Anthropologist 83:320-363.

Steward, Julian $\mathrm{H}$

1949 Cultural Causality and Law: A Trial Formulation of the Development of Early Civilizations. American Anthropologist 51:1-27.

1955 Theory of Culture Change: The Methodology of Multilinear Evolution. University of Illinois Press, Urbana.

1971 [1955] Some Implications of the Symposium. In Prehistoric Agriculture, edited by S. Struever, pp. 614-648. The Natural History Press, Garden City, New York. Reprinted. Originally published 1955, in Irrigation Civilizations: A Comparative Study, edited by J. H. Steward, R. M. Adams, D. Collier, A. Palerm, Karl A. Wittfogel, and R. L. Beals. Pan American Union Press, Washington, D.C.

Strong, William D., and Clifford Evans, Jr.

1952 Cultural Stratigraphy in the Virú Valley, Northern Peru. Columbia Studies in Archaeology and Ethnology 4. Columbia University Press, New York.

Tello, Ricardo

1998 Los conjuntos arquitectónicos 8, 17, 18, y 19 del centro urbano Moche. In Investigaciones en la Huaca de la Luna 1996, edited by S. Uceda, E. Mujica, and R. Morales, pp. 117-138. Facultad de Ciencias Sociales, Universidad Nacional de la Libertad-Trujillo, Peru.

Topic, Theresa

1977 Excavations at Moche. Unpublished Ph.D. dissertation, Department of Anthropology, Harvard University, Cambridge.

1982 The Early Intermediate Period and Its Legacy. In Chan Chan: Andean Desert City, edited by M. E. Moseley and K.
C. Day, pp. 255-284. University of New Mexico Press, Albuquerque.

Topic, Theresa, and John Topic

1982 Prehistoric Fortifications of Northern Peru: Preliminary Report of the Final Season January-December 1980. Unpublished manuscript on file at the Department of Anthropology, Trent University, Peterborough, Ontario.

Trubitt, Mary Beth D.

2000 Mound Building and Prestige Good Exchange: Changing Strategies in the Cahokia Chiefdom. American Antiquity 65:669-690

Uceda, Santiago

1997 El poder y la muerte in la sociedad de Moche. In Investigaciones en la Huaca de la Luna 1995, edited by S. Uceda, E. Mujica, and R. Morales, pp. 177-188. Facultad de Ciencias Sociales, Universidad Nacional de la Libertad-Trujillo, Peru.

Uceda, Santiago, and Josè Armas

1997 Los talleres alfareros en el centro urbano Moche . In Investigaciones en la Huaca de la Luna 1995, edited by S. Uceda, E. Mujica, and R. Morales, pp. 93-104. Facultad de Ciencias Sociales, Universidad Nacional de la Libertad-Trujillo, Peru.

1998 An Urban Pottery Workshop at the Site of Moche. In Andean Ceramics: Technology, Organization, and Approaches, edited by I. Shimada, pp. 91-110. MASCA Research Papers in Science and Archaeology, Supplement to Volume 15. University of Pennsylvania Museum of Anthropology and Archaeology, Philadelphia.

Uceda, Santiago, Elías Mujica, and Ricardo Morales (editors) 1997 Investigaciones en la Huaca de la Luna 1995. Facultad de Ciencias Sociales, Universidad Nacional de la LibertadTrujillo, Peru.

1998 Investigaciones en la Huaca de la Luna 1996. Facultad de Ciencias Sociales, Universidad Nacional de la LibertadTrujillo, Peru.

Upham, Steadman

1982 Politics and Power: An Economic and Political History of the Western Pueblo Indians. Academic Press, New York.

Van Gijseghem, Hendrik

2001 Household and Family at Moche, Peru: An Analysis of Building and Residence Patterns in a Prehispanic Urban Center. Latin American Antiquity 12:257-273.

Verano, John W.

2001 The Physical Evidence of Human Sacrifice in Ancient Peru. In Ritual Sacrifice in Ancient Peru, edited by E. P. Benson and A. G. Cook, pp. 165-184. University of Texas Press, Austin.

Waylen, Peter R., and Cesar N. Caviedes

1986 El Niño and Annual Floods on the North Peruvian Littoral. Journal of Hydrology 89:141-156.

White, Leslie

1949 The Science of Culture. Farrar, Straus, \& Giroux, New York.

Willey, Gordon R.

1953 Prehistoric Settlement Patterns in the Virú Valley, Perú. Bulletin 155, Smithsonian Institution Bureau of American Ethnology. United States Government Printing Office, Washington, D.C.

Wilson, David J.

1988 Prehispanic Settlement Patterns in the Lower Santa Valley, Peru. Smithsonian Institution Press, Washington, D.C.

1995 Prehistoric Settlement Patterns in the Casma Valley, North Coast of Peru: Preliminary Results to Date. Journal of the Steward Anthropological Society 23:189-227.

Wittfogel, Karl A. 
1956 The Hydraulic Civilizations. In Man's Role in Changing the Face of the Earth, edited by W. Thomas, pp. 152-164. Wenner-Gren Foundation, Chicago.

1957 Oriental Despotism. Yale University Press, New Haven, Connecticut.

1971 Developmental Aspects of Hydraulic Societies. In Prehistoric Agriculture, edited by S. Struever, pp. 557-571. The Natural History Press, Garden City, New York. Reprinted. Originally published 1955, in Irrigation Civilizations: A Comparative Study, edited by J. H. Steward, R. M. Adams, D. Collier, A. Palerm, Karl A. Wittfogel, and R. L. Beals. Pan American Union Press, Washington, D.C.

Wright, Henry T., and Gregory A. Johnson

1975 Population, Exchange, and Early State Evolution in Southwestern Iran. American Anthropologist 77:267-289.

\section{Notes}

1. Among cultures and even individuals in the same culture, the length of a workday varies. An eight-hour day is used here as a standardized convention for comparing labor investment in canals.

2. An alternative explanation is that the farmers observed by Gillin were leaving certain fields unplanted because of water shortages. According to records complied by ONERN (1973:183), during the years of Gillin's study (1938-1944), only one year was a drought year (1938), two years had low volume but still could support over 11,000 ha of corn, and four years had high volumes. Surprisingly, planting occurred during the three lowest volume years, and fallowing occurred in high volume years. Therefore, fallowing practices recorded by Gillin do not appear to be the result of water shortages.

3. Use of proxy records from the eastern slope of the southern Andes, such as the ice cores from the Quelccaya Ice Cap, may also be problematic. Within the north coast, river flow volume in any given year varies significantly among rivers. For instance, Waylen and Caviedes (1986) have demonstrated that droughts and El Niños do not affect all valleys equally. Some valleys, such as the Moche Valley, are much more resistant to regional fluctuations in river volume. Given the problems of correlating river volume within the region, it is unclear whether one can infer a long-distance teleconnection between the Moche watershed and proxy records of precipitation on the eastern slope of the southern Andes.

4. Calibrated using M. Stuiver, P. J. Reimer, and R. Reimer's calibration program. Executed online at http://depts.washington.edu/qil/calib/.

5. Based on 7,076 ha on the north side of the lower valley (Moseley and Deeds 1982: Table 2.1), between 3,200 and 3,750 ha on the south side (Moseley and Deeds 1982:Table 2.1), and 2,262 ha in the middle valley (ONERN 1973:154-155). The resulting figure is rounded to 12,550 and 13,200 ha.

Received January 21, 1998; accepted September 30, 2000; revised January 24, 2002. 